\title{
norden
}

\section{Marine Littering and Sources in Nordic Waters}



4 norden 



\section{Marine Littering and Sources in Nordic Waters}

Eva Blidberg, Anne Lise Bekken, Aija Bäckström, Hanna Haaksi, Liv-Marit Hansen, Mali Hole Skogen, Bjarke Lembrecht Frandsen, Tomas Thernström and Jessica Ångström 
Marine Littering and Sources in Nordic Waters

Eva Blidberg, Anne Lise Bekken, Aija Bäckström, Hanna Haaksi, Liv-Marit Hansen, Mali Hole Skogen, Bjarke Lembrecht Frandsen, Tomas Thernström and Jessica Ångström

ISBN 978-92-893-4061-8 (PRINT)

ISBN 978-92-893-4063-2 (PDF)

ISBN 978-92-893-4062-5 (EPUB)

http://dx.doi.org/10.6027/TN2015-524

TemaNord 2015:524

ISSN 0908-6692

(C) Nordic Council of Ministers 2015

Layout: Hanne Lebech

Cover photo: Keep Sweden Tidy

Print: Rosendahls-Schultz Grafisk

Printed in Denmark

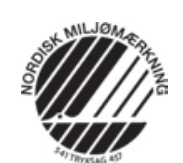

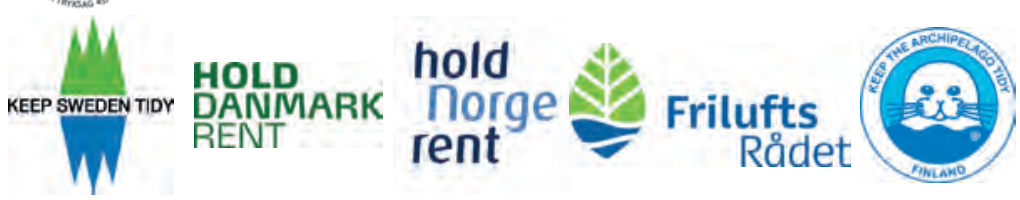

\section{(F) Oslofjordens \\ $\Leftrightarrow$ Friluftsråd}

This publication has been published with financial support by the Nordic Council of Ministers. However, the contents of this publication do not necessarily reflect the views, policies or recommendations of the Nordic Council of Ministers.

www.norden.org/en/publications

Nordic co-operation

Nordic co-operation is one of the world's most extensive forms of regional collaboration, involving Denmark, Finland, Iceland, Norway, Sweden, and the Faroe Islands, Greenland, and Åland.

Nordic co-operation has firm traditions in politics, the economy, and culture. It plays an important role in European and international collaboration, and aims at creating a strong Nordic community in a strong Europe.

Nordic co-operation seeks to safeguard Nordic and regional interests and principles in the global community. Common Nordic values help the region solidify its position as one of the world's most innovative and competitive.

\section{Nordic Council of Ministers}

Ved Stranden 18

DK-1061 Copenhagen K

Phone (+45) 33960200

\section{www.norden.org}




\section{Content}

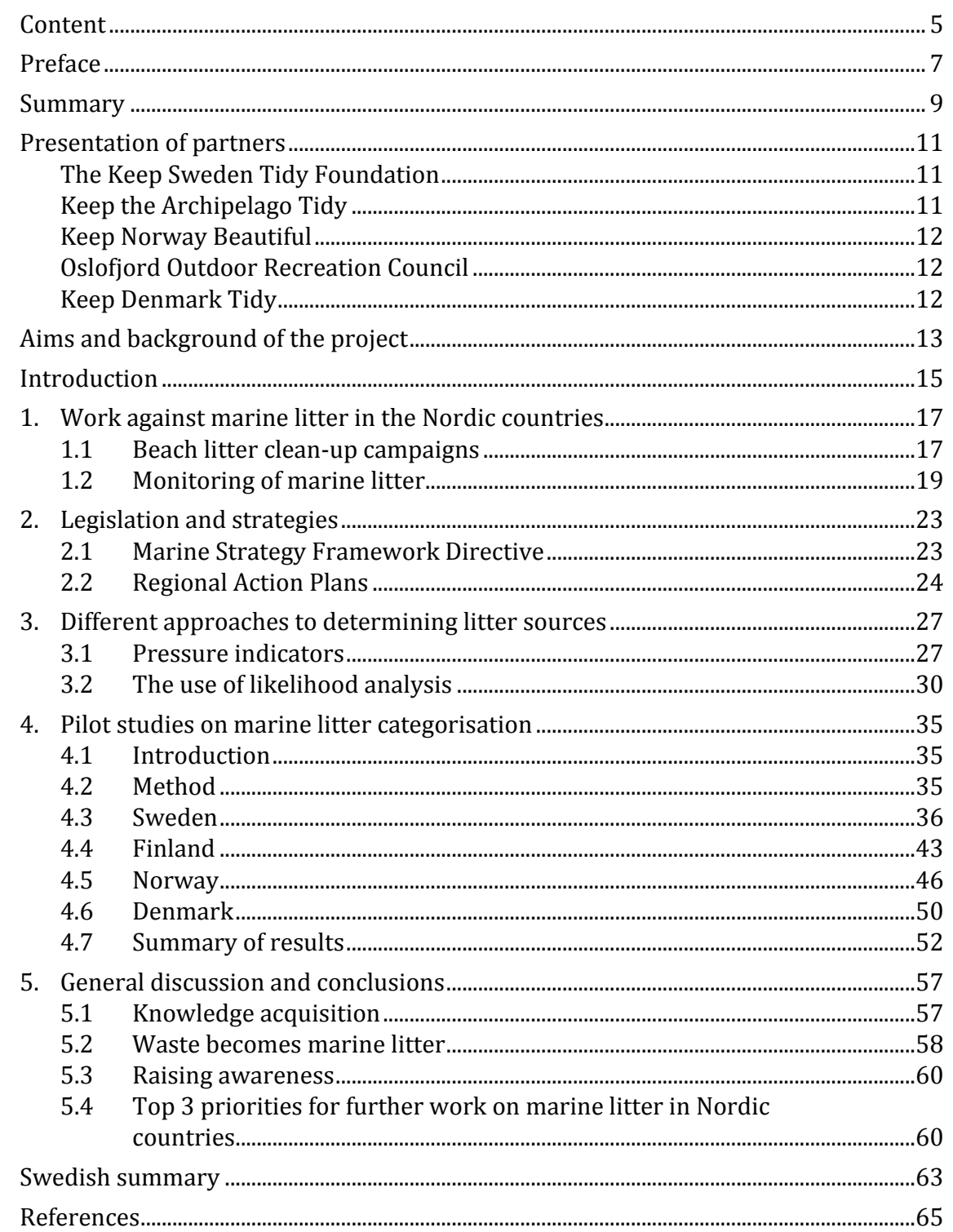





\section{Preface}

The story of marine litter begins on land!

Marine litter is one of the largest threats to the marine environment in our time. Animals and birds are taken marine litter for food and are caught in the litter, in many cases fatal or with long-time suffering. Moreover have marine littering negative socio-economical and aesthetic consequences. Most marine litter items are made by plastic material. Million tons of plastic ends up in the sea and remains there for hundreds of years. This is litter that no one feels responsible for or cleans up. Moreover is marine litter one of our most unnecessary environmental problems. There is every reason to take marine littering seriously and to have the courage to set targets for litter mitigation goals.

A general view is that 80 percent of the marine litter comes from land-based sources. Marine litter is hereby a larger problem directly coupled to the production of goods and our consumption as well as the solid waste management. In order to find cost-effective measures to decrease the amount of waste that become litter, the litter sources have to be identified.

In this project, Nordic NGOs have as a first step, expanded their current activities i.e. clean up campaigns and beach litter monitoring and categorized beach litter items from a product perspective. This gives a possibility to also distinguish producers or sectors of producers so that directed actions can be taken. Acquisition of knowledge is considered as a key success factor in combating against littering, as well as raising awareness of the problem and work on a policy level. The project has developed a "Top 3 priorities list" for further work on marine litter in Nordic countries. We moreover hope that our results can give guidance in the work with the action plans against marine littering that are under development within EU countries and HELCOM, as well as contribute with information to the work with OSPAR Marine litter regional action plan for the North Sea. 
For the future, I hold a picture of a society where the use of circular economy is for all given. A society where we do not use unnecessary packaging, where we take care of our waste in a proper manner, and where we do not throw litter in nature. It cannot be so difficult, can it?

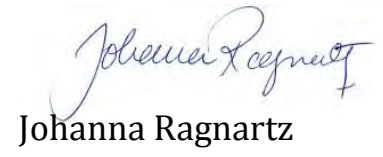

CEO, Keep Sweden Tidy 


\section{Summary}

Marine litter is a global environmental problem that endangers sensitive marine ecosystems and wildlife. It also has major socio-economic and aesthetic impact and is strongly connected to a sustainable society. Most marine litter consists of plastic material and it is generally accepted that $80 \%$ of marine litter comes from land-based sources. Identifying these sources is an important key to proposing cost-effective measures. The background to this project is a joint interest by Nordic NGOs to collaborate and expand upon their current activities e.g. clean-up campaigns and monitoring of beach litter. A model for litter categorisation from a product perspective is introduced in order to identify targeted measures to reduce marine litter.

The pilot studies in the project are based on pick analyses of litter items collected during clean-up campaigns or in connection with beach litter monitoring. The results confirm that the most common types of litter found on beaches in all Nordic countries are made of plastic and polystyrene. Short-life items and packaging were the most common product types, strongly linking littering to individual consumers, although it should be noted that the litter can originate far beyond the borders of the Nordic countries. Consequently, marine litter is largely a product of modern production and consumption. By contrast, litter from the beach studied in Norway had a higher proportion of industrial packaging from, for instance, the fishing and agricultural sectors, as well as packaging related to the transport of goods.

The project has shown that it is feasible to obtain further information on litter items from both monitoring surveys and beach cleanups. To ensure high quality data, information from monitoring surveys is preferable but the statistical basis may become less. NGOs and grassroots level organisations have an important role in the collection, analysis and storage of such information. Measures relating to policy targets for waste recycling are discussed along with the proposed changes to the Waste Framework Directive. Producers are charged with greater responsibility and expected to support prevention and clean-up initiatives financially. Suggested goals include a $30 \%$ reduction in the ten most common beach litter items and fishing industry waste found at sea by 2020 . It is concluded that the plastics and packaging industry 
has an important role in this context. Raising public awareness by arranging beach litter clean-up events is further suggested as an important measure in the reduction of marine litter.

Even if the regional action plans in HELCOM and OSPAR support cooperation between riparian states, it would be beneficial if the Nordic countries could continue to share data. This includes identification of both litter composition and origin, for the dissemination and sharing of national knowledge and experience. Other measures include cooperation around clean-up activities, e.g. by arranging a Nordic Beach cleanup day. In this way, Nordic NGOs can be even more successful in their work against marine litter. 


\title{
Presentation of partners
}

\author{
The Keep Sweden Tidy Foundation
}

The Keep Sweden Tidy Foundation shapes public opinion that promotes recycling and combats littering via public awareness campaigns, awards and environmental education. The Foundation strives to influence public attitudes and behaviour in order to encourage sustainable development.

The Swedish Environmental Protection Agency and the company Returpack established the Foundation in 1983. Its origins, however, are in the Keep Nature Tidy campaign that was launched in 1963 by the Swedish Society for Nature Conservation. Keep Sweden Tidy is financed by an annual allowance from the founders, and to a larger extent through external financing from the private and public sectors. Keep Sweden Tidy is the lead partner in this project.

Participants: Jessica Ångström, Tomas Thernström and Eva Blidberg.

\section{Keep the Archipelago Tidy}

The Finnish organisation Keep the Archipelago Tidy was founded in 1969. It is a nationwide non-profit organisation active in environmental protection in many fields: waste collection, recycling, information and education. The organisation began as an initiative of individuals in the archipelago area and later spread to coastal areas and the Finnish Lake District. Today it has approximately 13,000 members, mainly recreational boaters. The Keep the Archipelago Tidy organisation is best known for its nearly 200 "Rubbish Seal" waste recycling bins around Finland, where recreational boaters can bring their waste. In addition, the organisation has approximately 200 earth closets/dry toilets and about 30 pump-out stations. In addition to these established services, the organisation has also started special local projects, which all contribute to creating a better future for our marine environments.

Participants: Hanna Hakksi and Aija Bäckström. 


\section{Keep Norway Beautiful}

Keep Norway Beautiful was founded by the Norwegian Sanitation Works association, now Norway Waste Management, in 2004. The impetus for the establishment of Keep Norway Beautiful was an increase in litter in public spaces, necessitating a national campaign. Keep Norway Beautiful works for a litter-free Norway, and motivates individuals, organisations and businesses to gather litter throughout the country. In 2011, Keep Norway Beautiful was one of the founders of the Beach Clean Day. The organisation also works with attitudes to and information about litter.

Participant: Mali Hole Skogen.

\section{Oslofjord Outdoor Recreation Council}

Oslofjord Outdoor Recreation Council is an organisation founded in 1933. It is an internal municipal collaboration for municipalities, counties, associations and organisations, for the management of outdoor resources, promotion of outdoor activities, and maintenance of the natural environment around the Oslofjord. In 2014, 31 municipalities, 5 counties and 44 associations or organisations were members of the Oslofjord Outdoor Recreation Council. About 4,400 individuals are supporting members. Support from the Norwegian Environment Agency, Directorate of Health, Ministry of Culture, and membership fees from counties, municipalities, and associations finance the activity. In addition, the Recreation Council performs fund-raising activities.

Participants: Anne Lise Bekken and Liv-Marit Hansen.

\section{Keep Denmark Tidy}

Keep Denmark Tidy is a widely recognised Danish non-profit organisation whose main objective is reducing the amount of litter in Denmark. Through partnerships with public authorities, companies and the general public, Keep Denmark Tidy works to develop a better national understanding of the problem of litter, to support and coordinate local efforts to prevent and reduce litter, to increase awareness through campaigns and other communications media and to develop tools and products that can be of assistance in combating litter.

Participant: Bjarke Lembrecht Frandsen. 


\section{Aims and background of the project}

All the participating countries in the project have on-going campaigns and studies concerning marine litter. The main objective is to elaborate on these studies and introduce a model for litter categorisation in order to identify targeted measures to reduce marine litter. The project partners will jointly develop a protocol for that purpose. The results will contribute to the future development of action plans within the Marine Strategy Framework Directive. The overall goal of the project is to contribute to a reduction in marine litter.

Moreover, the aim is to get a general picture of the experience and knowledge of marine litter in the Nordic countries. The project will enable a closer collaboration between NGOs, who are the most active campaigners and collators of knowledge about marine litter. This will give a deeper understanding of the topic, and through a harmonised approach, more reliable data will also be obtained. In addition, the participants will use the results in public outreach and communication.

The impetus for the project is a joint interest by Nordic NGOs to collaborate and develop the activities they already carry out individually, e.g. clean-up campaigns and monitoring work. The partners in the project all have long experience of marine litter, and studying the provenance of beach litter is a natural continuation of that work. A holistic approach will be taken to increase knowledge and propose solutions for marine litter in Skagerrak, Kattegat and the Baltic Sea.

The project will only address beach litter, and the project is geographically limited since only four of five Nordic countries participate. Furthermore, the Nordic Council of Ministers will soon publish a literature study on marine litter in the Nordic countries (Strand, unpublished). Additionally is the marine litter situation in Norway presented in a recently published report by Standal et al. (2014). Therefore, this report does not strive to be comprehensive but will instead focus solely on what is relevant for the purposes of the project. 



\section{Introduction}

Marine litter ${ }^{1}$ is a global environmental problem caused entirely by human activities. Litter is found not only all along the coasts but also far out into the open seas that should be unaffected by human influence. Marine litter is also one of the most apparent problems found in the marine environment. Even so, it is only around $15 \%$ of the marine litter that reaches the coastline. The remainder stays in the water column $(15 \%)$ or on the seabed $(70 \%)$.

Marine litter endangers sensitive marine ecosystems and wildlife, and it has great socio-economic and aesthetic impact. This includes the negative impact of litter on beaches leading to a possible reduction in returns from tourism. Many coastal municipalities spend huge amounts of money annually cleaning beaches. Altogether, marine litter hinders the development of a sustainable society.

Most marine litter consists of plastic materials. Plastic is valued by the manufacturing industry for qualities such as low weight, durability and long degradation time. As waste however, these factors are purely negative. Lightweight composition makes it possible for the litter to travel long distances driven by ocean currents before reaching the coast, getting trapped in accumulation areas or sinking to the bottom. In the Pacific and Atlantic Oceans, there are areas with an estimated 100 million tonnes of waste, about $80 \%$ of which is plastic (European Commission, 2013). Additionally have Jambeck et al. (2015) calculated that 275 million metric tons of plastic waste was generated in 192 coastal countries in 2010, with 4.8 to 12.7 million million tons entering the ocean. A slow degradation rate, in many cases measured in hundreds of years, means that plastic does not naturally disappear from the environment. This results in an accumulation of plastic litter, since no one cleans the sea or takes responsibility for the litter.

Marine litter is a complex problem, and the primary and ultimate goal of measures to reduce it must be preventing the litter getting into the

\footnotetext{
${ }^{1}$ According to UNEP (2005) marine litter is defined as any persistent, manufactured or processed solid material discarded, disposed of or abandoned in the marine and coastal environment.
} 
sea in the first place. A wide range of measures across many different areas will be necessary in the future. Establishing the origin of litter is an important key to proposing cost-effective measures. Currently, there are few studies on sources of marine litter, and there is no established standardised method. In general, litter can originate from land- or seabased sources, but land-based sources are thought to contribute to a greater extent. It can however be difficult to determine the true origin of a single piece of litter, even in such broad terms.

Other weaknesses raised include, for instance, deficiencies in the implementation and enforcement of existing regulations. This, in combination with a lack of awareness among major stakeholders and the general public, prevents an improvement of the problem. ${ }^{2}$ Furthermore, marine litter is part of the broader problem of waste management. As the EU commission writes on their homepage, "Sadly, the persistence of marine litter is the result of poor practices of solid waste management, lack of infrastructure and a lack of awareness in the public at large about the consequences of their actions". ${ }^{3}$ Jambeck et al. (2015) also conclude that population size and the quality of waste management systems largely determine which countries contribute the greatest mass of uncaptured waste available to become plastic marine litter. Improvements in policy instruments to reduce marine litter have been thoroughly reported by IEEP (Newman et al., 2013). According to Mehlhart and Blepp (2012) national coordination and global strategies are still absent, although there has been an increased interest in the topic during the last 20 years.

2 UNEP: http://www.unep.org/regionalseas/marinelitter/default.asp 2014-10-17.

${ }^{3}$ European Commission: http://ec.europa.eu/environment/marine/good-environmental-status/descriptor10/index_en.htm 2014-11-28. 


\section{Work against marine litter in the Nordic countries}

Beach litter clean-up campaigns and other work to reduce marine litter are conducted by several organisations in the Nordic countries. Usually, the main aims of clean-up campaigns are advocacy and raising awareness of the problem. Beach clean-up campaigns usually involve volunteers and have several advantages, e.g. reaching many people (the public, politicians, and organisations), cleaning large areas simultaneously and collecting large amounts of litter. Clean-ups can also provide information on the quantity and composition of marine litter and give a broad picture of the scale of the problem.

In the past few years, there has been a demand for more knowledge about marine litter. This has led to initiatives to find methods for quantifying beach litter, and to initiate monitoring programs. In several cases, NGOs have been at the forefront of this work.

Beach clean-up campaigns and environmental monitoring, presented below, are some examples of work carried out by Nordic NGOs. Since litter items from these activities are used in the pick analyses, they are considered relevant to the report.

\subsection{Beach litter clean-up campaigns}

\subsubsection{Sweden}

For decades, the Keep Sweden Tidy foundation has arranged clean-up events every spring. Around 700,000 individuals participate in this campaign annually. The campaign is primarily targeted at nurseries and schools, but also companies and organisations that collect litter in their local area. For the last three years, Keep Sweden Tidy has also organised an annual clean-up campaign specifically for marine litter along the Swedish coast - Clean-up Kust. The campaign was run for the first time in 2012 and in one day alone, 11 tons of litter was collected. In 2014, it was included in the European "Let's clean-up Europe" campaign and over 2,500 Swedish volunteers participated (Håll Sverige Rent, 2014). 
The main aim of the campaign is to raise public awareness of the problem, and to increase knowledge about marine litter in Sweden. Ultimately, it is hoped that the campaign will lead to a change in people's attitudes and behaviour towards littering.

\section{Figure 1. Swedish volunteers picking litter during a beach clean-up event}

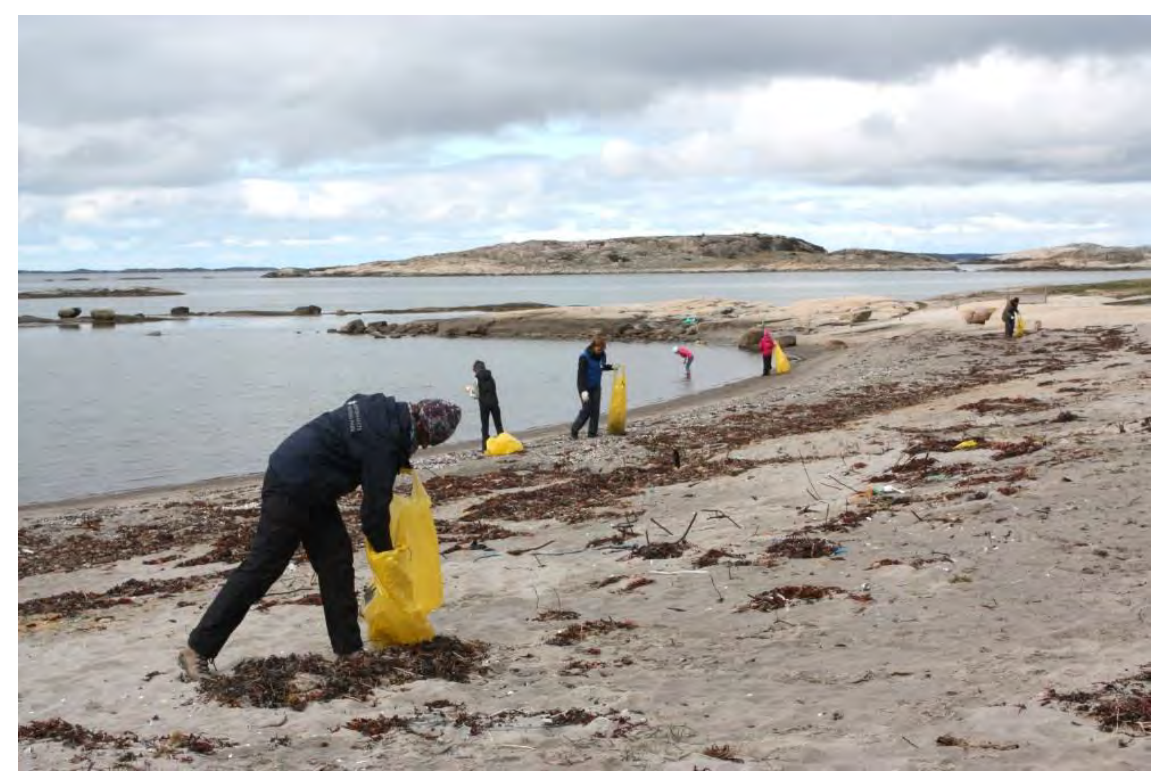

\subsubsection{Finland}

Keep the Archipelago Tidy organised a Siisti Biitsi/Snygg Beach campaign in the spring of 2014. During two weeks in May, different groups of volunteers or individuals cleaned beaches along the Finnish coast. Altogether 110 beaches/locations were cleaned, 1,464 people were involved and 67 reports of litter amounts were sent to Keep the Archipelago Tidy.

\subsubsection{Norway}

Keep Norway Beautiful works with marine litter nationally, and initiated the campaign Strandryddedagen, which has been organised since 2011. When the first campaign was arranged, around 2,000 individuals participated. In 2014, Strandryddedagen was a part of the European "Let's clean-up Europe" campaign. Over 12,000 volunteers were out gathering litter, cleaning about 522 beaches that together represent $320 \mathrm{~km}$ of coastline (Hole Skogen and Holen, 2014). 
Keep Norway Beautiful and Oslofjord Outdoor Recreation Council cooperate in several beach-cleaning activities. The organisations have also collaborated to produce educational material for schools and nurseries, including a beach-cleaning manual. ${ }^{4}$ The work aims to raise awareness about the problems marine litter causes.

\subsubsection{Denmark}

Keep Denmark Tidy has recurring Clean Beach Days when volunteers are invited to gather litter on beaches. Every year, approximately 2,500 volunteers, 98 schools (representing 65,000 pupils), 78 businesses (representing 40,000 employees) and 23 public authorities (representing 230,000 employees) participate in Keep Denmark Tidy's campaigns.

As an example, one company with 160 employees collected litter for 90 minutes resulting in a total of 23,069 pieces of litter at Amager Beach Park, a sandy beach outside Copenhagen.

Participants use a mobile application "the Marine Litter Watch app" to register what they find. The application is developed by the European Environment Agency. Data acquired on the litter items collected is then available to Keep Denmark Tidy for analysis. The results give a general picture of the beach litter situation in Denmark.

Keep Denmark Tidy also organised a beach litter prevention campaign in the summer of 2014. The campaign was called "Be a Beach Buddy" and it was carried out with the help of coastal lifeguards on 25 major beaches in Denmark. The campaign focus and message is to discourage littering at the beach, and to recycle litter when possible.

\subsection{Monitoring of marine litter}

\subsubsection{Marine litter in the Baltic Sea-MARLIN project}

The aim of the MARLIN project was to increase knowledge about marine litter in the Baltic Sea. This was done by introducing a common monitoring method for beach litter across the Central Baltic region, in combination with several activities intended to raise awareness. The project was necessary because existing data on the amounts, sources and type of

${ }^{4}$ Strandryddedagen 2014: http://holdnorgerent.no/ta-med-deg-klassen-ut-a-rydde-ei-strand/_2014-11-27. 
litter were insufficient and had been collected using different assessment methods (or no specific method at all). The results were not comparable, making it difficult to draw conclusions regarding litter prevention in the Baltic Sea. Therefore, a harmonised monitoring method ${ }^{5}$ for the Baltic Sea was developed by modifying the existing UNEP's method (Cheshire et al., 2009).

Marine litter assessments were carried out at 23 beaches in Sweden, Finland, Estonia and Latvia during 2012-2013. All data from these surveys was collected in a database that is still in use. The results show that litter on the Baltic Sea beaches mostly originates from visitors to the beaches themselves or nearby beaches. The amount of litter is higher at urban beaches with many visitors (237 items per $100 \mathrm{~m}$ ) than at rural beaches (76 items per $100 \mathrm{~m}$ ). The litter found on urban beaches correlated highly with our take away-lifestyle; bottle caps, plastic bags, plastic food containers, wrappers and plastic cutlery were common items. On rural beaches, more "industrial" litter items such as plastic ropes and construction materials were found. The findings indicate that litter from sea-based sources such as shipping does not end up on shores of the Baltic Sea to the same extent as it does in, for instance, the North East Atlantic Area. 56\% of the litter is made of plastic and the most common litter item overall was unidentified plastic or small plastic items (25\%).

A top 5 list of litter items found on the shores of the Baltic Sea:

- Various unidentifiable plastic items.

- Glass and ceramics fragments.

- Plastic bottle caps and lids.

- Plastic bags.

- Foamed plastic (packaging and insulation).

It should be noted that cigarette butts are not included in the top 5 list due to their small size. Nonetheless, cigarette butts are by far the most common litter item on beaches in the Baltic Sea area. On average, there are approximately 300 cigarette butts per $100 \mathrm{~m}$ at urban beaches.

Another aim of the project was to put marine litter on the daily agenda of the public and policymakers. This was done via activities to

${ }^{5}$ Marine litter in the Baltic Sea (MARLIN), Beach litter measurements method description: http://www.projectmarlin.eu/sa/node.asp?node=3009 2014-11-14. 
raise awareness about marine litter e.g. by a litter exhibition contest for children (Estonia), a beach walk in Riga bay (Latvia), collecting seabed litter in marinas (Sweden) and producing educational material for children (Finland).

The MARLIN project was funded by the Central Baltic INTERREG IV A Programme 2007-2013. The four partners were Keep Estonia Sea Tidy, Keep the Archipelago Tidy (Finland), FEE Latvia and Keep Sweden Tidy (lead partner).

\subsubsection{Marine litter in the North Sea-OSPAR monitoring}

The Greater North Sea is included in the OSPAR Convention ${ }^{6}$ maritime area. The northern part of the Swedish west coast (Bohuslän), the northwest coast of Denmark and southern part of Norway are part of the monitoring programme for this marine region. OSPAR beach litter surveys have been conducted since 2000, compiling data on amounts and composition of litter. The measurements use a harmonised methodology, and the data is considered to be reliable.

The latest comprehensive UNEP report for the North Sea is from 2009 with analysed OSPAR data from 2002-2008 (OSPAR, 2009). In summary, the results showed that:

- The marine litter distribution in the North Sea varies considerably between locations.

- The northern part of the North Sea has the highest concentrations of beach litter (600-1,400 items/100 m) compared to the southern part (200-600 items/100 m).

- The most common litter materials were plastic and polystyrene. On average, $75 \%$ of the litter items were plastic. ${ }^{7}$

- The most common items were ropes and nets (30\%) followed by packaging (28\%). 
- The second most common litter category was sanitary items (average $4.5 \%)$.

- No general trends over time in the weight or number of beach litter items were found.

In a report by Mehlhart and Blepp (2012), a diagram summarises the sources of marine litter in the North Sea based on OSPAR data. The most important land-based source is "shoreline and recreational actions" (35\%), with almost as much coming from sea-based sources (33\%). Dumping activities comprised $7 \%$ of the land-based sources, and $42 \%$ of the marine litter was unidentified.

In Bohuslän, beach litter surveys have been performed on six beaches, four times per year, since 2001. The County Administrative Board of Västra Götaland is responsible for the measurements. OSPAR beach litter data (2001-2011) from Bohuslän has been analysed by Svärd (2013). Selected results state that:

- The amount of beach litter has not decreased since 2001 .

- The number of litter items varies between $211-2,171$ items per $100 \mathrm{~m}$.

- $25-30 \%$ more plastic litter is found during and after the winter season compared to other seasons.

- Strong winds increase the amount of litter by $37 \%$.

- Litter associated with tourism and beach activities are found on the beach in equal or greater amounts in winter than in summer. This indicates that this type of litter has, at least partly, been brought to the coast from the North Sea. 


\section{Legislation and strategies}

Litter items can originate from land-based or sea-based sources. Currents and winds independently of national borders transport marine litter, further complicating the problem. International laws and agreements regarding marine litter are therefore of great importance, and there are a numerous policy instruments linked to reducing marine litter. Newman et al. (2013) identify six laws within the EU that have a high potential impact on the mitigation of marine litter: The Marine Strategy Framework Directive (MSDF) (2008/56/EC), The Waste Framework Directive (2008/98/EC), the Packaging and Packaging Waste Directive (94/62/EC), the Cosmetics Regulation (Regulation (EC) No 1223/2009), and the European Maritime and Fisheries Fund (Regulation (EU) No 508/2014). The MSFD can be considered as the "core" legislation against marine litter within the EU, and it is briefly described below.

Norway has not implemented the MSFD, but they have signed the OSPAR convention and established management plans for their various marine environments e.g. Management of the Marine Environment of the Barents Sea and the Sea Areas off the Lofoten Islands.

There are also important strategy documents related to reducing marine litter. The two Regional Action Plans for the Baltic Sea and the North Sea are reported here, as they are relevant for areas that influence the Nordic countries.

\subsection{Marine Strategy Framework Directive}

The Marine Strategy Framework Directive is an EU legislative instrument, which aims to achieve Good Environmental Status (GES) of the EU's marine waters by 2020 and to protect the resource base upon which marine-related economic and social activities depend. The Directive has an ecosystem approach to the management of human activi- 
ties having an impact on the marine environment, integrating the concepts of environmental protection and sustainable use. ${ }^{8}$

One of the descriptors ( $\mathrm{nr}$ 10) in the MSFD addresses marine litter. Four qualitative indicators are set to determine GES. It includes marine litter on coastlines, in the water column and on the seafloor, microparticles in the sea and litter ingested by marine animals. The amount of litter on the coastline is proposed as a main indicator for marine litter pollution (10.1.1) characterised as "trends in the amounts of litter washed ashore and/or deposited on coastlines, including analyses of its composition, spatial distribution and, where possible, source" (European Commission, 2010). It is further suggested that volunteers can be used to carry out monitoring surveys of beach litter (JCR-IES, 2013).

The national authorities of EU countries are now in the process of developing indicators and setting reduction targets in agreement with the MSFD. The indicator demands national marine litter monitoring programs to determine long-term trends.

\subsection{Regional Action Plans}

\subsubsection{HELCOM}

Baltic Marine Environment Protection Commission - Helsinki Commission or HELCOM is a governing body of member states around the Baltic Sea cooperating to protect the marine environment from all sources of pollution. The Baltic Sea Action Plan (BSAP) was adopted in 2007 and is a strategic policy document for HELCOM's work and a restoration programme with the vision to achieve good ecological status of the Baltic marine environment by 2021. The BSAP aims to set specific ecological objectives and measurable targets in line with the ecosystem approach. The goal is to implement these targets through national programmes and regional interventions. BSAP works predominantly with the effects of eutrophication, biodiversity, hazardous substances and maritime activities.

Marine litter represents an important area for action. In 2013 it was agreed that HELCOM would develop a regional action plan on marine

\footnotetext{
${ }^{8}$ European Commission: (http://ec.europa.eu/environment/marine/eu-coast-and-marine-policy/marinestrategy-framework-directive/index_en.htm) 2014-10-07.
} 
litter with the aim of achieving a significant reduction of marine litter by 2025 and to prevent harm to the coastal and marine environment. The action plan is intended to be adopted in 2015. HELCOM's vision for the action plan is as follows: "The regional action plan for marine litter should enable concrete measures for prevention and reduction of marine litter from its main sources; develop common indicators and associated targets related to quantities, composition, sources and pathways of marine litter; and to identify the socio-economic and biological impacts of marine litter." 9

\subsubsection{OSPAR}

The Convention for the Protection of the marine Environment of the North-East Atlantic ${ }^{10}$ (The OSPAR Convention) deals with prevention and elimination of pollution from land-based sources, dumping or incineration, and offshore sources. It also includes assessments of the quality of the marine environment. The aim of the OSPAR Commission, made up of representatives of the Governments of 15 Contracting Parties and the European Commission, representing the European Union, is protecting and conserving the North-East Atlantic and its resources.

The OSPAR Biological Diversity and Ecosystems Strategy include a list of the human activities that can adversely affect the marine environment. Programmes and measures are developed in relation to these human activities. They include e.g. dumping waste, offshore windfarms, and tourism. Some impacts on the marine environment, including marine litter, are the result of a variety of activities and are assessed in this context.

At the OSPAR meeting in June 2014, the Commission agreed upon the Regional Action Plan for Prevention and Management of Marine Litter in the North-East Atlantic. ${ }^{11}$ This Regional Action Plan sets out the policy context for OSPAR's work on marine litter, describes the various types of actions that OSPAR will work on in the coming years, and provides a timetable for the achievement of these actions.

\footnotetext{
${ }^{9}$ HELCOM: http://helcom.fi/action-areas/waste-water-litter/marine-litter-action-plan/ 2014-10-08. 10 OSPAR Commission: http://www.ospar.org/ 2015-02-10.

11 OSPAR RAP: http://ospar.org/documents/dbase/publications/p00643/p00643_mlrap_brochure.pdf 2015-02-10.
} 



\section{Different approaches to determining litter sources}

As mentioned earlier, extensive action will be required in many different areas to meet existing and future marine litter reduction targets. Establishing the source of the litter helps to determine where effective measures should be taken to reduce the number of products that become waste, and which ultimately might end up in the sea or on the beaches as litter. Information on the sources of litter should be seen as complementary to the amounts and composition of beach litter, as outlined in the Marine Strategy Framework Directive (MSFD) (see Chapter 5.1).

Litter on beaches is often partially degraded and fragmented, and it may be difficult to identify and categorise the litter. Another problem is that a specific piece of litter can belong to multiple source categories. Summerised below are, however, two interesting recently-published reports with different approaches to tackling the problem of marine litter sources.

\subsection{Pressure indicators}

In a study by Mehlhart and Blepp (2012) literature of land-sourced litter in the marine environment is reviewed and different aspects of the problems with marine litter are discussed. Moreover, the impact of landsourced litter is assessed using pressure indicators in order to identify potential litter sources. Pressure indicators are described as a method to evaluate the risk of pollution with land-based sources i.e. plastic waste. This is an interesting approach since it is commonly agreed that $80 \%$ of marine litter originates on land, with plastic material dominating. 
In the report, pressure estimates for a town, municipality, or region are made using data available on Eurostat. ${ }^{12}$

The following potential litter sources and impacts are presented:

\section{- Population density}

Population density is a general indicator for potential pressure for land-sourced litter. This is based on the fact that more people generate more waste. This indicator should be combined with factors that reduce the pressure of population density, e.g. advanced wastewater treatment.

\section{- Tourism and recreation}

The total number of overnight stays is suggested as an indicator for potential pressures. Leisure activities and tourism contribute significantly to the amount of litter on beaches and other tourist sites along coasts. Local authorities spend a lot of money every year cleaning these areas. Other possible indicators suggested are: Level of litter (inland/seashore) and litter caused by tourism/recreational visitors/events at the coast. Many other factors need to be accounted for to get the whole picture, e.g. cultural attitudes to litter.

\section{- Port activities}

The law regulates the handling of ship-generated waste and cargo residues. Despite this, ports may be an important source for marine litter due to careless handling of waste. According to the authors, no reliable information is available regarding this issue. The amount of goods loaded and unloaded in ports annually can be used as an indicator of the potential pressure. Other factors include waste management at the port and passenger traffic in the region.

- Solid waste management

Several sources have been identified: collection and treatment of municipal waste, management of waste from dump sites located near coasts or riverbanks/rivers, management of plastic packaging waste, management of commercial and industrial waste, and management of agricultural plastic waste.

12 Eurostat is the statistical office of the European Union. Its task is to provide the European Union with statistics at European level that enable comparisons between countries and regions. 
Eurostat identifies three different strategies for municipal waste management:

1) Countries that apply a combined strategy with high rates of more than $25 \%$ for material recovery (composting and recycling) as well as incineration.

2) Countries where the systems of recycling and composting are established to an extent that a high rate of material recovery of more than $25 \%$ is achieved.

3) Countries that rely on landfill as a treatment option, with equally low rates of less than $25 \%$ for incineration and material recovery.

The authors also included a Group 4 with "less advanced waste management". This refers to countries that are still dumping waste along riverbanks and seashores.

\section{- Waste water treatment}

No indicator for wastewater treatment is established in the report. However, coverage of collection (sewer) and treatment as well as sewer overflow, combined sewer overflow is identified as sources. During heavy rain, systems can be exceeded and sewage is directly discharged without treatment.

The authors estimate the pressure for the different countries around the Baltic Sea, North Sea and Mediterranean. The pressure indicates the potential amount of land-based litter. The calculation takes into account regional differences e.g. length of coastline, ocean depth and more. No combined indicator was developed in the study, but some differences in the structures and pressure for the different regions could still be seen.

For the purposes of this project, only national pressure data for the areas of interest is presented i.e. the Baltic Sea and the North Sea (Table 1 and 2). The indicator for population density varies greatly depending on location. In general, the population of the catchment area for the Baltic Sea is given as 85 million and for the North Sea 184 million people. The pressure indicator of tourism is given in general terms for the entire region; the Baltic Sea has $\sim 128$ million and the North Sea has $\sim 136$ million overnight stays in the region. Illustrative maps are shown in the report. 
Table 1. Data on length of coastline and national pressure for the Baltic Sea

\begin{tabular}{lrrrr}
\hline $\begin{array}{l}\text { Riparian } \\
\text { states of the } \\
\text { Baltic Sea }\end{array}$ & $\begin{array}{r}\text { Coastline (km) and } \\
\text { percentage of total } \\
\text { length of coastline } \\
\mathbf{( X \% )}\end{array}$ & $\begin{array}{r}\text { Different municipal- } \\
\text { ity waste manage- } \\
\text { ment and strategy }\end{array}$ & $\begin{array}{r}\text { Plastic packaging } \\
\text { to be disposed of } \\
\text { in 2008 (kg per } \\
\text { capita and year) }\end{array}$ & $\begin{array}{r}\text { Commercial freight } \\
\text { at port (1,000 t per } \\
\text { year, average } \\
\text { 2008-2010) }\end{array}$ \\
\hline Sweden & $13,567(37 \%)$ & 1 & 7.8 & 128,642 \\
Finland & $14,018(38 \%)$ & 2 & 11.1 & 15,991 \\
Denmark & $3,070(8 \%)$ & 1 & 0.7 & 77,337 \\
Estonia & $2,549(7 \%)$ & 3 & 41.5 & 29,339 \\
Germany & $2,009(5 \%)$ & 1 & 1.2 & 51,441 \\
Poland & $634(2 \%)$ & 3 & 12.0 & 40,520 \\
Latvia & $534(1 \%)$ & 3 & 12.1 & 49,179 \\
Russia & $400(1 \%)$ & 4 & $12.5 *$ & Ca 150,000 \\
Lithuania & $262(1 \%)$ & 3 & 12.8 & 29,498 \\
\hline
\end{tabular}

*Default value only.

Table 2. Data on length of coastline and national pressure for the North Sea

\begin{tabular}{lrrrr}
\hline $\begin{array}{l}\text { Riparian } \\
\text { states of the } \\
\text { North Sea }\end{array}$ & $\begin{array}{r}\text { Coastline (km) and } \\
\text { percentage of total } \\
\text { length of coastline } \\
\mathbf{( X \% )}\end{array}$ & $\begin{array}{r}\text { Different municipali- } \\
\text { ty waste manage- } \\
\text { ment and strategy }\end{array}$ & $\begin{array}{r}\text { Plastic packaging } \\
\text { to be disposed of } \\
\text { in 2008 (kg per } \\
\text { capita and year) }\end{array}$ & $\begin{array}{r}\text { Commercial freight } \\
\text { at port (1,000 t per } \\
\text { year, average } \\
\text { 2008-2010) }\end{array}$ \\
\hline Denmark & $1,535(11 \%)$ & 1 & 0.7 & 77,337 \\
UK & $8,691(66 \%)$ & 2 & 24.4 & 427,054 \\
Germany & $1,515(11 \%)$ & 1 & 1.2 & 184,899 \\
Netherlands & $1,275(10 \%)$ & 1 & 1.2 & 419,444 \\
Belgium & $98(1 \%)$ & 1 & 3.9 & 184,593 \\
France & Ca 70 (1\%) & & & \\
Norway & n.a.* & 1 & 4.4 & \\
\hline
\end{tabular}

*Data not available.

The authors conclude that the Baltic Sea has the lowest pressure of population density, tourism activities and port activity in relation to the length of the coast. The North Sea has the highest pressure from port activity. Countries with high population density and many tourists combined with undeveloped waste management and low recycling of plastic packaging has the highest risk of producing land-based litter.

\subsection{The use of likelihood analysis}

In order to identify litter sources in relation to marine litter monitoring methods, ARCADIS (2012) published a report for the European Commission. The aim of this pilot study was to identify the main driving factors impacting on marine litter i.e. plastic waste that escapes legitimate management systems. This includes sources, gaps, loopholes and vectors. The background for the study is that the most cost effective measure against marine litter is to avoid waste reaching the marine environment. 
However, litter prevention requires that the source is identified, and it is often difficult to determine the origin of a litter item. One way to solve this problem is by using the attribution of likelihoods. The methodology is called "Matrix Scoring Technique" (Tudor and Willams, 2004). This means that a single item type can be assigned to multiple sources, but with different likelihoods. The attribution of likelihoods was made based on the type of litter, distance to each source, dimension of the activity in the area, waste management practices, and any other local factor known to contribute to littering. Local stakeholders scoring them in interviews determined the likelihood for different litter items, and the relative contribution of the different sources was then calculated.

The parameters included in the analysis are presented in Table 3.

Table 3. Parameters included in the likelihoods study, divided in the number of levels included in the analysis

\begin{tabular}{lll}
\hline One single selection & Attribute likelihoods (4 levels) & Attribute likelihoods (6 levels) \\
\hline Material & Life cycle phase & Sector of origin \\
Use category & Main origin & \\
Packing type & Release & \\
Use durability & Pathways & \\
Source activity & Geography of origin & \\
Fragmenting & Risk/impact & \\
\hline
\end{tabular}

The investigation includes four case studies representing the Baltic Sea (Riga), the North Sea (Oostende), the Mediterranean Sea (Barcelona), and the Black Sea (Constanta). Existing beach litter monitoring data were used and most of the measurements followed the OSPAR methodology for beach litter monitoring.

The marine litter sources included were:

- Agriculture.

- Aquaculture.

- Construction and demolition.

- Coastal/Beach Tourism.

- Dump sites/landfills.

- Fishing.

- General Household.

- Other industrial activities.

- Other maritime industries. 
- Ports.

- Recreational boating.

- Recreational fishing.

- Shipping.

- Toilet.

- Waste collection/transport.

The method for likelihood analysis that is used in the pilot study by ARCADIS (2012) is also applied in a following report for the European Commission (ARCADIS, 2013). This comprehensive report has the task to support the development of quantitative reduction targets for marine litter. The proposals in the report aim to promote a good marine status regarding marine litter in European seas.

The main differences of the likelihood analyses in these two reports are the amount of data used. The analysis in the latest report includes a larger set of OSPAR screenings from the whole region instead of local data from the sites in the case studies used in the pilot study. In the final report were also the likelihoods from the pilot study extrapolated and predefined as standard likelihoods for each regional sea.

Here are marine (beach) litter results from the Baltic Sea and the North Sea (ARCADIS, 2013) presented since these regions are interesting for the present study.

\subsubsection{Selected results for the Baltic Sea}

- Land-based activities are the dominant source (71\%) for marine litter items.

- $42 \%$ of the litter items were likely discarded on site.

- Only $19 \%$ of the litter items are potentially transported over a longer distance.

- The coast beach tourism sector $(24 \%)$ and the recreational fishing sector (14\%) are the most important sectors contributing to marine litter.

- Individual consumers (48\%) tend to make a larger contribution to marine litter than professionals (17\%).

- Most of the litter items are categorized as use items (62\%) and less are packaging (36\%).

- Single-use and long lasting use items occur in equal proportion (49\%). 
- Plastic pieces with sizes between $2.5 \mathrm{~cm}$ and $50(24 \%)$ are the dominant part, followed by cigarette butts $(10 \%)$, based on numbers of litter items.

- Plastic material is the dominant fraction (58\%), followed by items made of paper/cardboard (17\%), metal (7\%) and ceramic (6\%).

\subsubsection{Selected results for the North Sea}

- $57 \%$ of the litter items are likely to origin from land-based activities.

- $30 \%$ of the beach litter items is potentially transported over a longer distance, $35 \%$ of the items is transported over a short distance from the site, with $35 \%$ produced/discarded on site.

- The main contributing sectors are coastal/beach tourism (18\%), professional fishing (13\%) and the shipping sector (9\%).

- Consumers have a contribution with $33 \%$ of the litter items. $40 \%$ of the marine litter items are likely to be related to professional activities, resulting in a higher share (51\%) of long lasting use items.

- Plastic/polystyrene pieces are the dominant part (32\%) of litter items, followed by string and cord items $(12 \%)$.

- The dominant material is plastic (80-85\%) followed by clothes (fabric) (5\%) and items made of paper/cardboard (2\%), processed wood $(2 \%)$, rubber (2\%) and metal (2\%). 



\section{Pilot studies on marine litter categorisation}

\subsection{Introduction}

The purpose of this pilot study was to identify and categorise beach litter items from a product perspective. This included the sector that presumably used the product before it became waste, as well as by product type and duration of use. The goal was to identify the main actors that can contribute to a reduction in marine litter. The results are important in raising these actors' awareness, which is in turn an important piece of the puzzle in reducing marine litter.

This pilot study can be seen as a complement to other approaches of litter source studies e.g. ARCADIS (2012) where sectors of origin (agriculture, aquaculture etc.) are identified.

With the approach used in this pilot study, it did not include a determination of the type of litter items found. Not all participating countries analysed this parameter. To give an example of the litter that may be more predominant at Nordic beaches, a "Top 10 list 2014" from clean-up events in Sweden and Norway is presented in Summary of results, Chapter 4.7.

\subsection{Method}

Pick analysis is a method to characterise waste by sorting each litter item by hand into different categories. In this pilot study, every item of litter was categorised according to a protocol to show the composition, source activity, use durability, use category, and degradation time.

Composition is defined as the main material of which the litter is composed. The other parameters are divided into to the following subdivisions: 


\section{Source activity}

- Individual consumers.

- Industry/Professional.

- Unknown.

\section{Use durability}

- Short life/Single use.

- Long-lasting item.

- Multiple-dose/use

\section{Use category}

- Packaging.

- Use item.

- Recreational item.

- Raw material.

\section{Fragmentation/degradation time}

- Less than 100 years.

- More than 100 years.

The protocol for the pick analyses was developed by the project participants and is partly based on parameters used in the likelihood analysis developed by ARCADIS (2012).

The parameters were chosen with the purpose of identifying which kinds of litter are most commonly found at beaches and how they could be categorised. It provides important information about which products most commonly end up as litter.

\subsection{Sweden}

\subsubsection{General information}

Pick analyses were conducted in conjunction with Clean-up Kust on the 10th of May 2014. Over 2,500 volunteers participated in the campaign along large parts of the Swedish coast. Keep Sweden Tidy was present on 10 beaches along Bohuslän and Skånes coast. At three of these locations, the litter collected was saved for a more detailed analysis. The 
selected beaches were: a) Nötholmen and Saltpannan, Strömstad in northern Bohuslän, b) Askimsbadet, Gothenburg in southern Bohuslän, c) Fortuna Beach, Helsingborg at the west coast of Skåne. The beaches are used for recreation, swimming, boating, and other purposes.

The number of litter items collected was 12,733 in total with 1,871 pieces from Strömstad, 6,116 pieces from Gothenburg, and 4,746 pieces from Helsingborg.

The results from the campaign are also presented in the Swedish report Kusträddarna 2014 (Håll Sverige Rent, 2014).

\section{Figure 2. Sorted litter in one of the Swedish pick analyses}
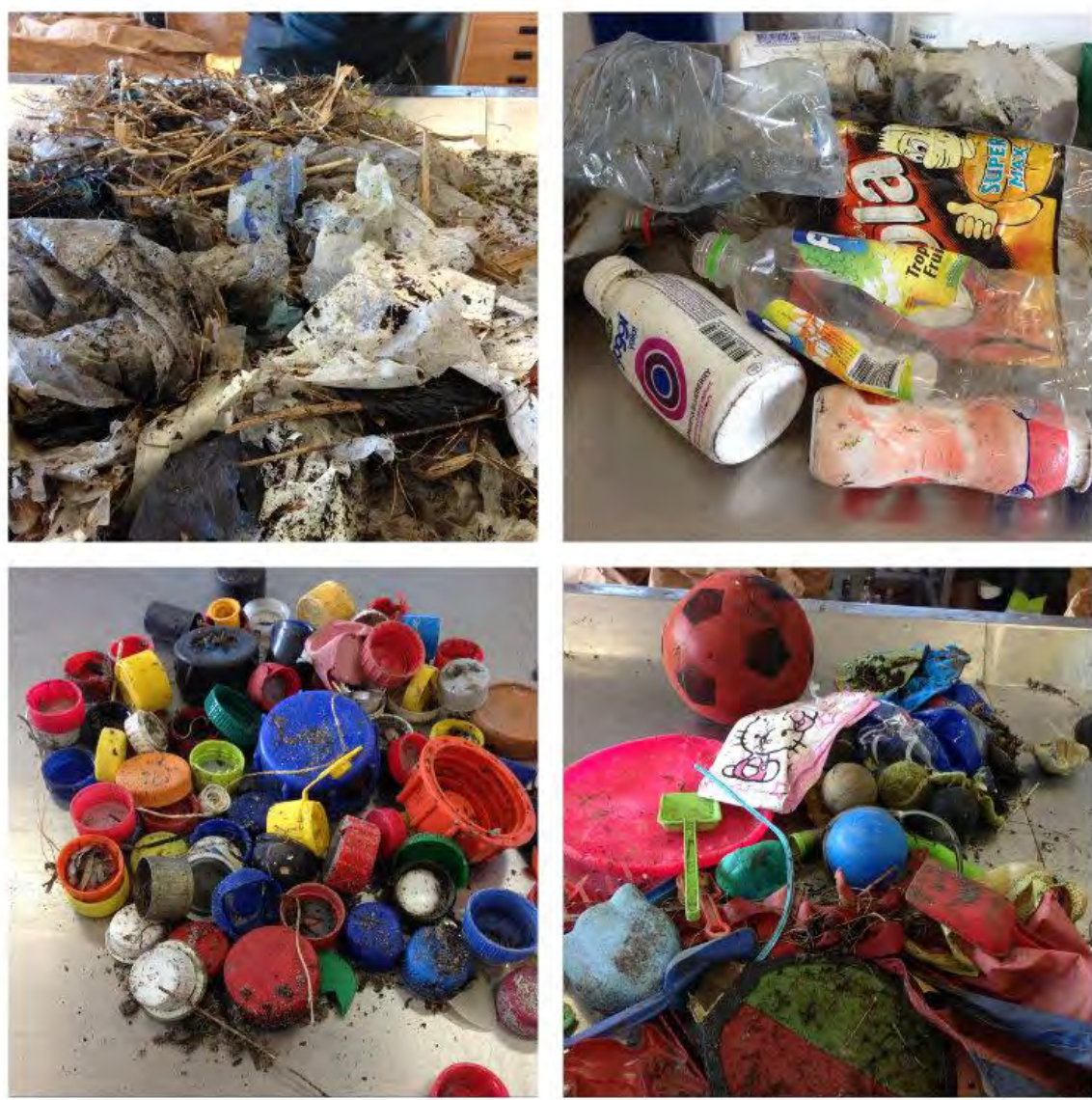


\subsubsection{Results and discussion}

The litter was divided into different material types. The most common materials found on the three beaches are shown in Figure 3-5. In all areas the analyses show that between $84-89 \%$ of the material consists of plastic and polystyrene. This is consistent with results from similar studies of other beaches around the world. Other materials e.g. paper/corrugated paper, glass and metal are only small fractions of the total.

Figure 3. The most common material types (\% of total number of litter items) of marine litter at Nötholmen and Saltpannan in Strömstad, Sweden. Categories with few objects (<1\%) include; wood, rubber, ceramics/porcelain, textile/clothes, dog faeces in bags and other hazardous waste

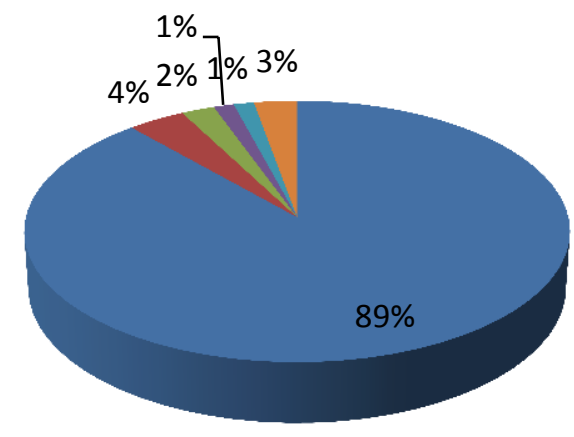

Plastic and
polystyrene
Paper/corrugated
paper
Glass
Metal
Other
Categories with few
objects


Figure 4. The most common material types (\% of total number of litter items) of marine litter at Askimsbadet in Gothenburg, Sweden. Categories with few objects (<1\%) include; ceramics/porcelain, textile/clothes, dog faeces in bags, other hazardous waste, and sanitary items

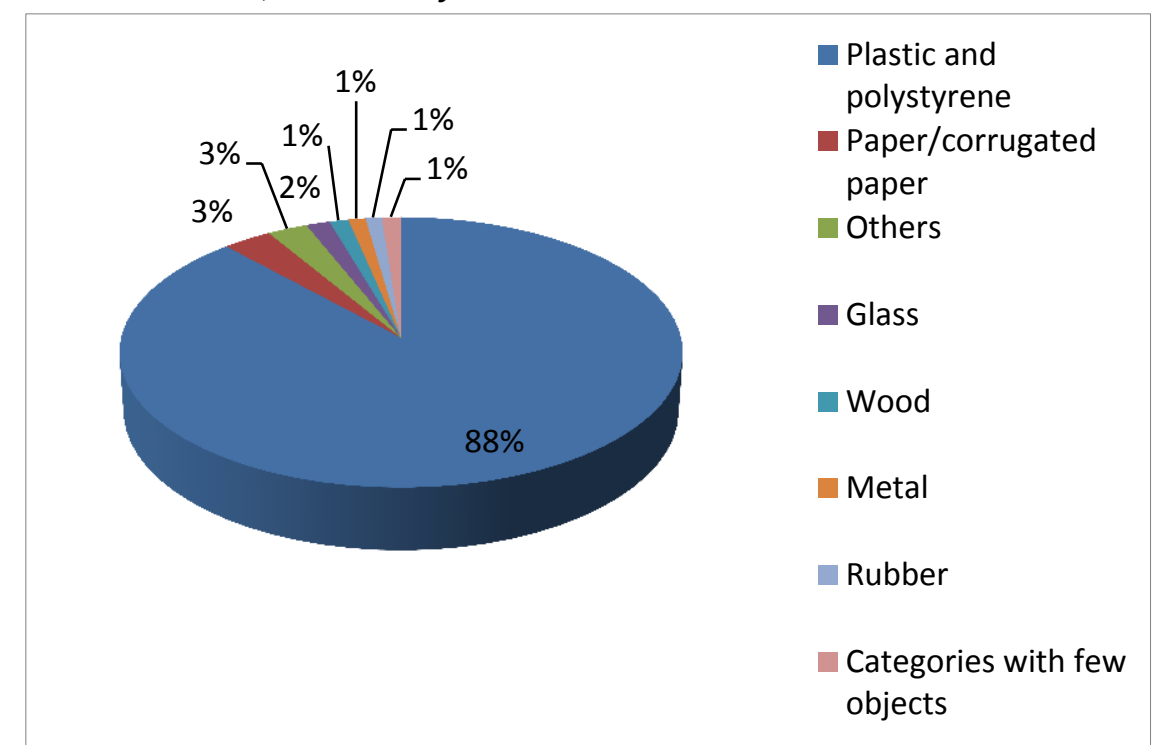

Figure 5. The most common material types (\% of total number of litter items) of marine litter at Fortuna Beach in Helsingborg, Sweden. Categories with few objects (<1\%) include; wood, ceramics/porcelain, textile/clothes, dog faeces in bags, other hazardous waste, sanitary items, medical items and glass

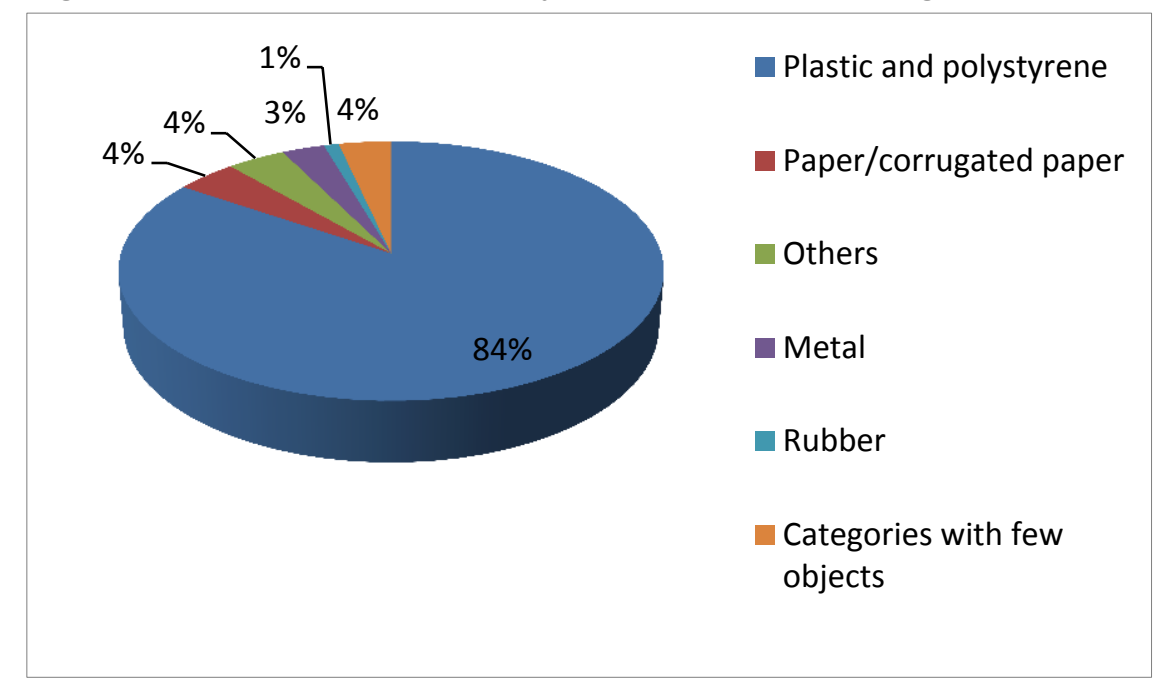


The analyses also show that the majority of marine litter consists of consumer items (Figure 6), that is items not directly related to industrial activity. Strömstad and Gothenburg had $71 \%$ and $87 \%$ respectively of items from this category. Helsingborg had $42 \%$ of litter items categorised as individual consumer waste. This may be because it was impossible to categorise the source activity for many litter items in Helsingborg.

It should be noted that even if a litter item is categorised as coming from individual consumers, it is not necessarily local litter. The items may have travelled great distances before ending up on the beach.

Figure 6. Marine litter divided into source activities (\% of total number of litter items) of the three beaches studied in Sweden and average results of the three beaches

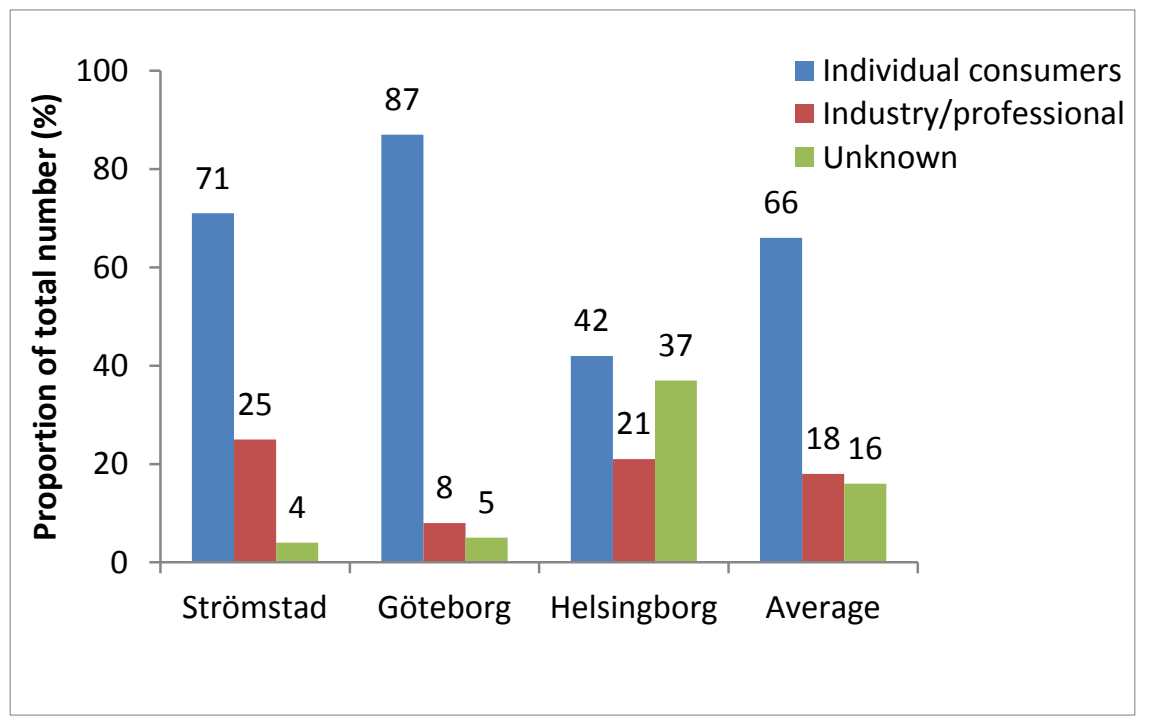


Use durability is presented in Figure 7. Short-lifetime or single use are the most common litter types found in this study (55-86\%), independent of location. Examples of litter items in this category are cigarettes, fast food packaging and candy papers. Helsingborg had more long usage items e.g. cigarette lighters, sun cream bottles etc. than the other beaches.

Figure 7. Marine litter divided into use durability (\% of total number of litter items) from the beaches studied in Sweden and average results of the three beaches

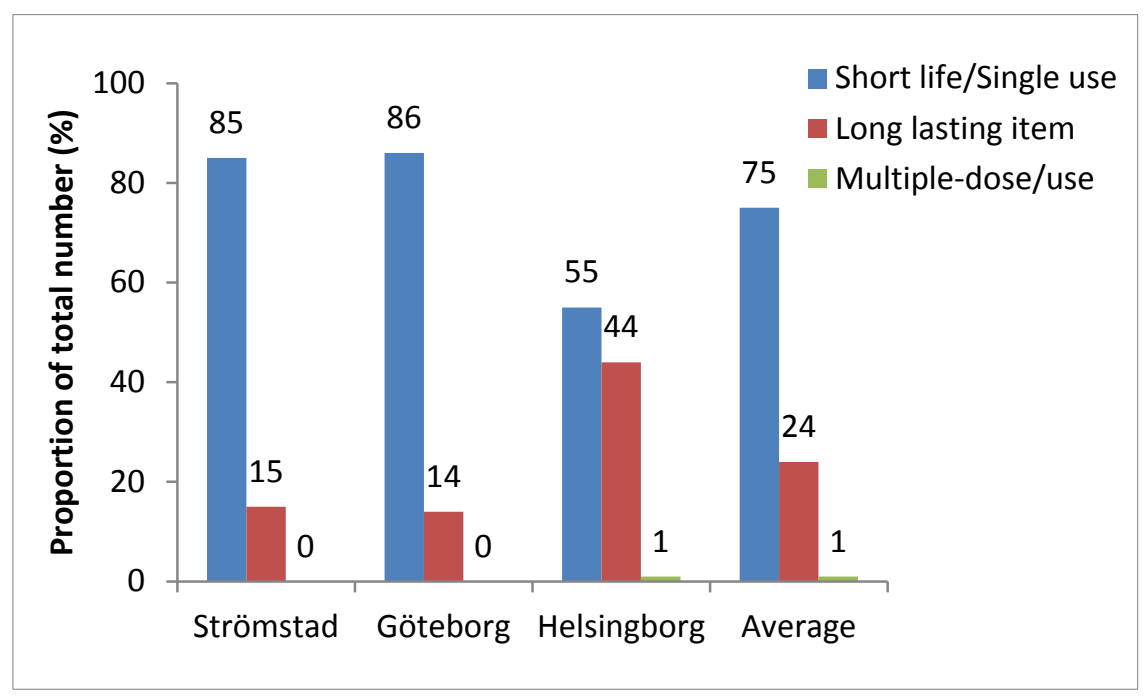

Litter items were also identified by use categories as this is often linked to the usage time. Four categories were identified, but only three of them are presented in Figure 8; packaging, use items and recreational products. No litter items were found in the category of "raw material" on any beach. Packaging was the most common litter type in Strömstad and Gothenburg, $81 \%$ and $77 \%$ respectively. In Helsingborg, approximately equal amounts of packaging and use items were found. Very few recreational items were found, regardless of beach. 
Figure 8. Marine litter divided into use categories (\% of total number of litter items) from the beaches studied in Sweden and average results of the three beaches

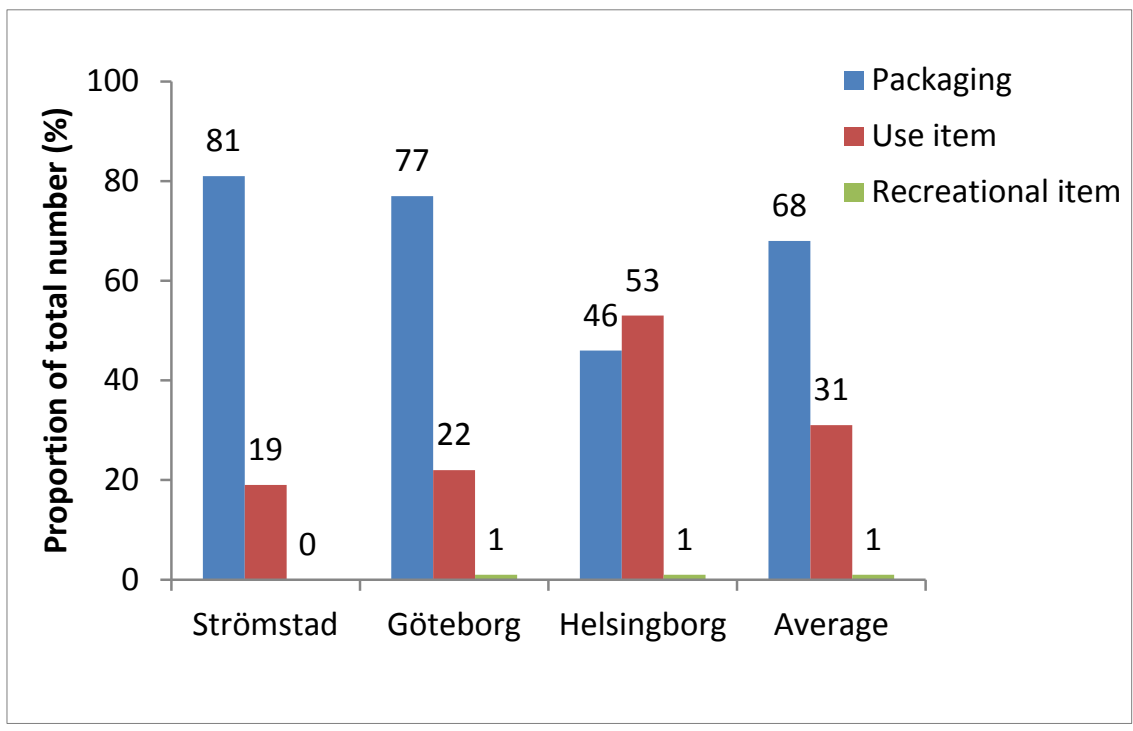

Finally, items were analysed according to their fragmentation/degradation time. ${ }^{13}$ In total, $93 \%$ of them had a degradation time of 100 years or more.

The Swedish pick analyses show that mainly plastic disposables were found on the beaches. These products are predominantly packaging e.g. bags, bottles and cans, which correlate to a higher degree with individual consumers than industrial activities. If no one cleans the beaches or feels responsible for the litter, it will accumulate and stay in nature for a very long time, due to its long degradation time.

The litter was analysed systematically, but the collection method was unscientific, because volunteers gathered it during a clean-up activity. Individuals may be prone to favouring some litter categories over others, which may affect the results.

${ }^{13}$ Degradation times for marine litter are rough estimates and depend on parameters such as abrasion, salinity, $\mathrm{pH}$, sunlight, and etc. 


\subsection{Finland}

\subsubsection{General information}

Keep the Archipelago Tidy association conducted beach assessments at nine beaches along the Finnish southern coast, consisting of three beach cleaning assessments per beach, per year. Beach assessments are performed according to the method developed in the MARLIN-project, ${ }^{14}$ which is based on the UNEP method (Cheshire et al., 2009).

Two beaches from the assessment program were chosen to be included in the litter source study, Utö and Mustfinn. During the summer of 2014, litter from these beaches was used in pick analyses. 99 litter items were found on Mustfinn, and only 12 on Utö. It should be noted that this is few litter items compared to corresponding analyses in the other countries. The litter items could not be identified with regard to origin or degradation time due to lack of information.

Utö is a rural beach, facing the open sea on a remote island in the outer archipelago, with about 20 permanent inhabitants. Mustfinn is a peri-urban beach, popular for bathing in the summer and located close to intensively trafficked shipping and recreational boating route.

\subsubsection{Results and discussion}

Plastic is the most common material for litter items from the Finnish beaches, 59\% for Utö (Figure 9) and 50\% for Mustfinn (Figure 10). This is comparable with the proportion of plastic found on other beaches around the world, although in the lower range. Metal was the second most common material found on both shores. Mustfinn contained more types of material compared with Utö, presumably because Utö is rural while Mustfinn is a recreational beach. It could also be because more litter items were found on Mustfinn than on Utö.

14 MARLIN:_www.projectmarlin.eu 2014-12-02.http://www.projectmarlin.eu/ 
Figure 9. The most common material types (\% of total number of litter items) of marine litter at Utö, Finland

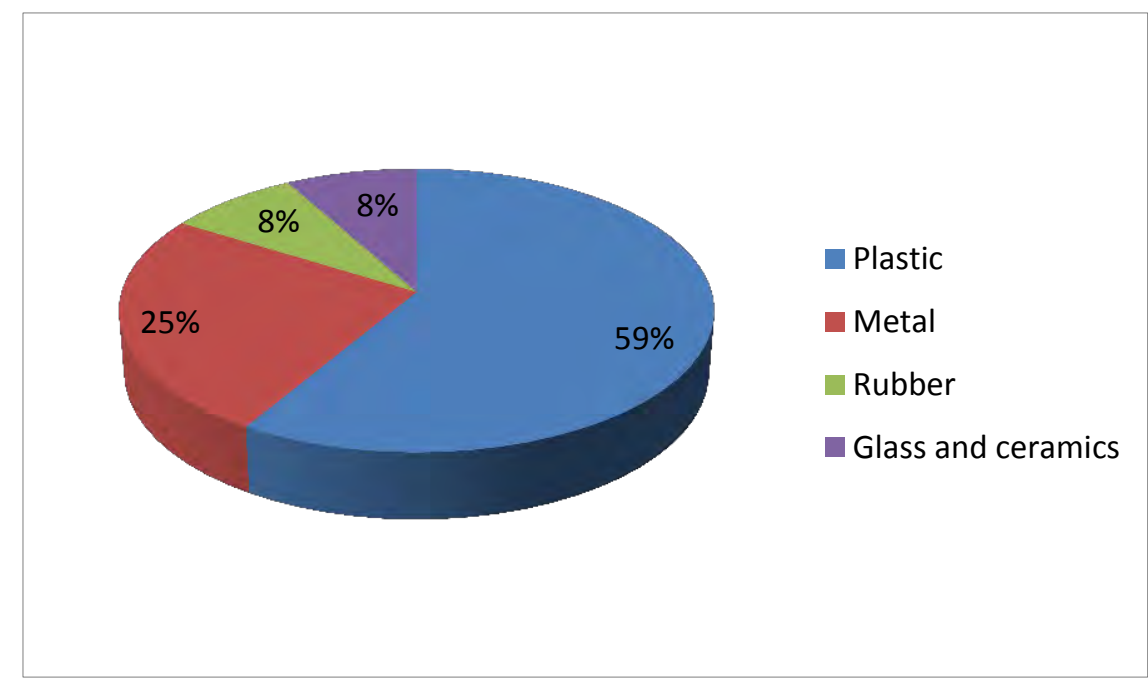

Figure 10. The most common material types (\% of total number of litter items) of marine litter at Mustfinn, Finland

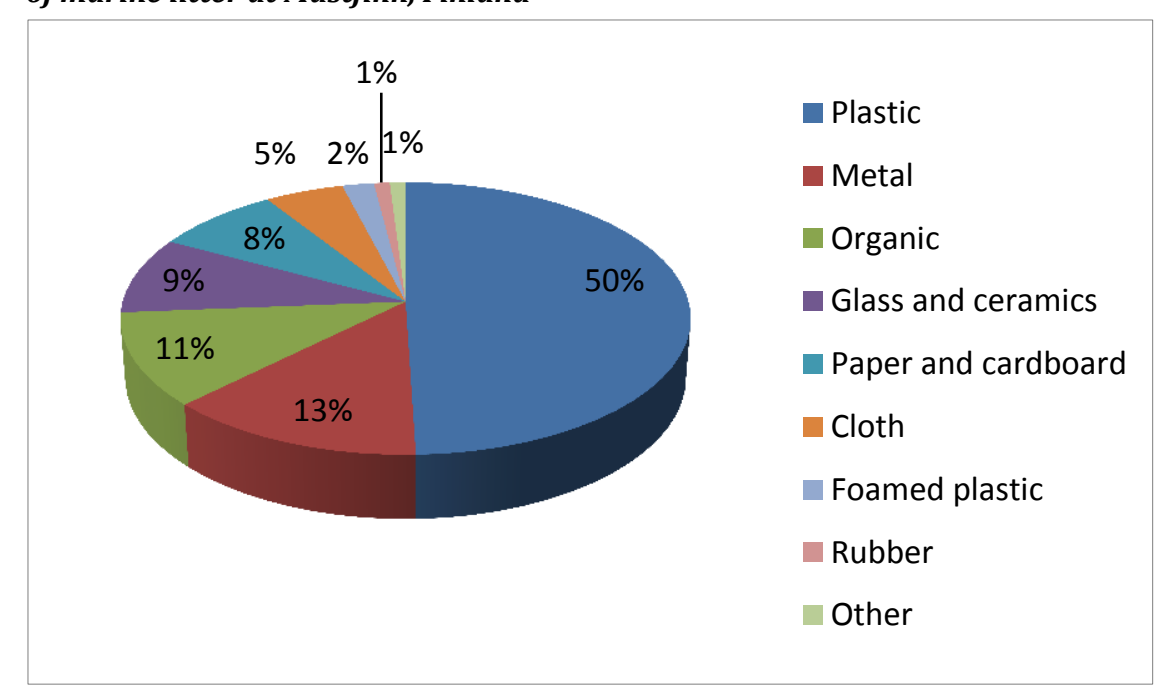


For the two beaches studied in Finland, similar results were found regarding use durability (Figure 11). The majority of the litter was single use items, $83 \%$ at Utö and $92 \%$ at Mustfinn.

Figure 11. Marine litter divided into use durability (\% of total number of litter items) from the beaches studied in Finland and average results of both beaches

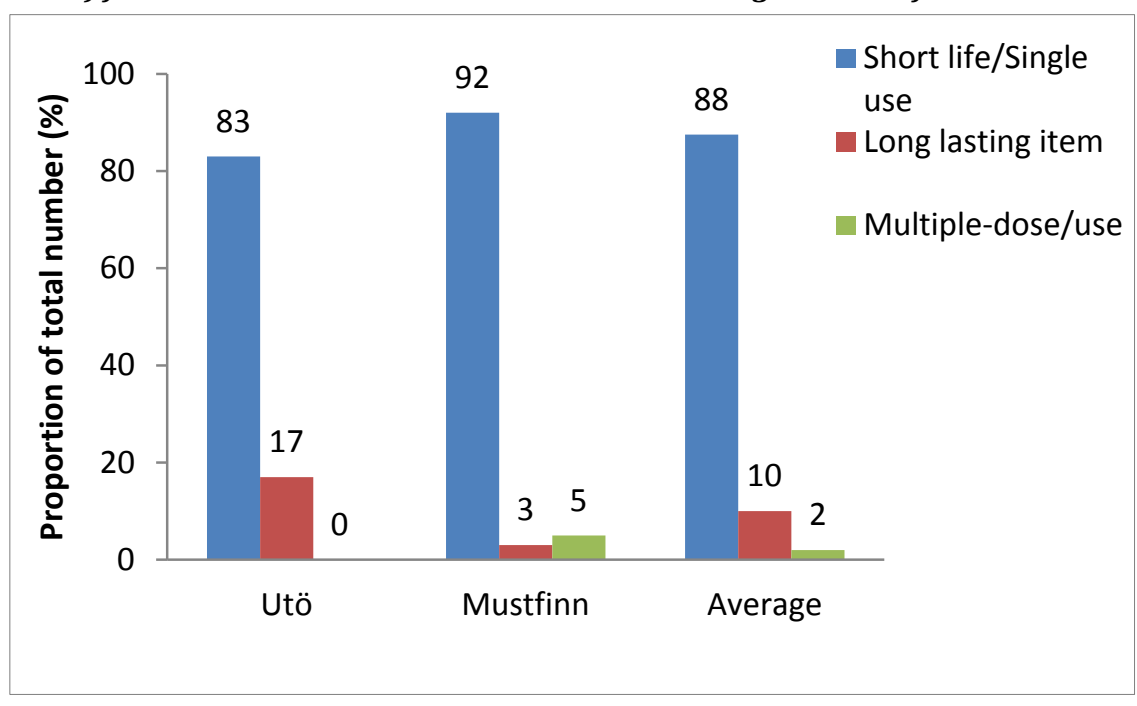

Figure 12. Marine litter divided into use categories (\% of total number of litter items) from the beaches studied in Finland and average results of both beaches

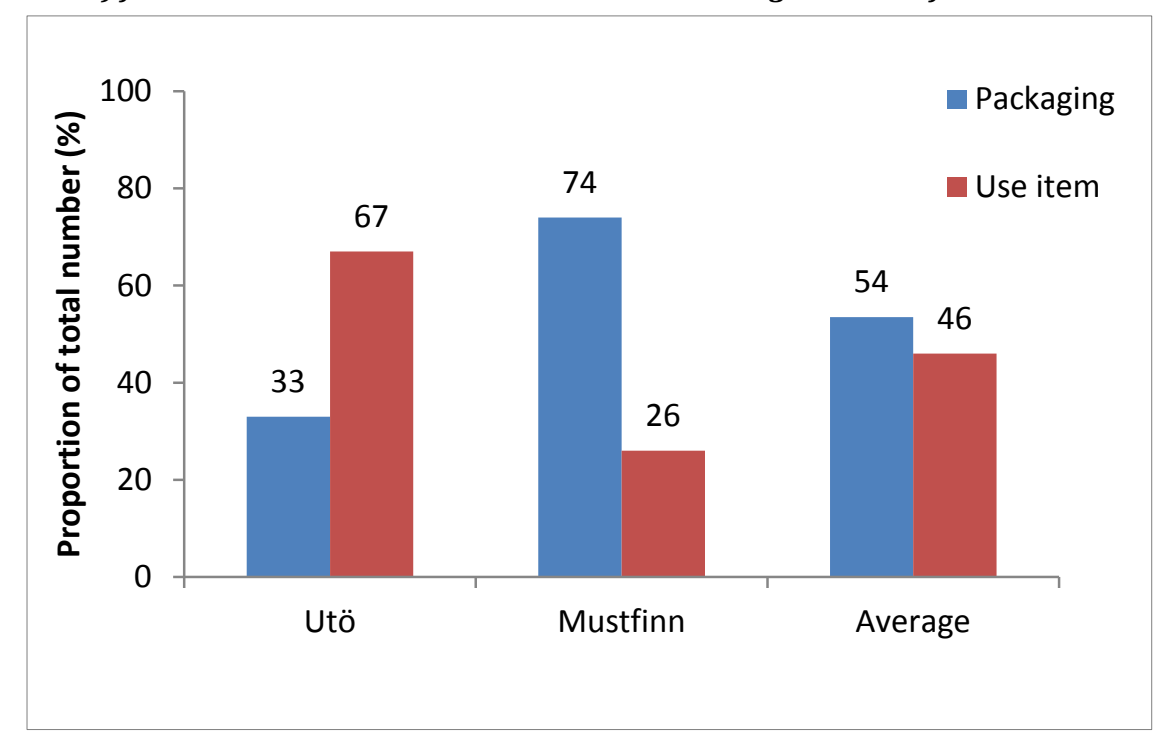


There were clear differences in the use categories between the beaches (Figure 12). The litter found at Utö beach was use items (67\%) while Mustfinn had only $26 \%$ use items and $74 \%$ packaging. At Mustfinn, most of the material found consisted of single-use items, with packaging being the most common category. The difference in how the beaches are used is the most obvious explanation for this. Whereas Utö is a rural beach with few visitors, Mustfinn is frequently used by swimmers in the summer and therefore has a higher potential for litter associated with visitors.

\subsection{Norway}

\subsubsection{General information}

Oslofjord Outdoor Recreation Council conducted the collection of beach litter together with the Norwegian Environmental Department in Norway on the 10th October 2014. Oslofjord Outdoor Recreation Council then performed the pick analysis. The beach, Selskjarsbukta, is situated on Håøya, which is the largest island in the inner part of Oslofjord. The beach is defined as rural/peri-urban and is mainly used by paddlers and hikers. The beach faces south and consequently receives a great deal of litter from the Skagerrak and the outer Oslofjord. Littering directly at the beach itself is minimal. 
Figure 13. A photo of beach litter at Selskjarsbukta on Håøya, Norway 2014

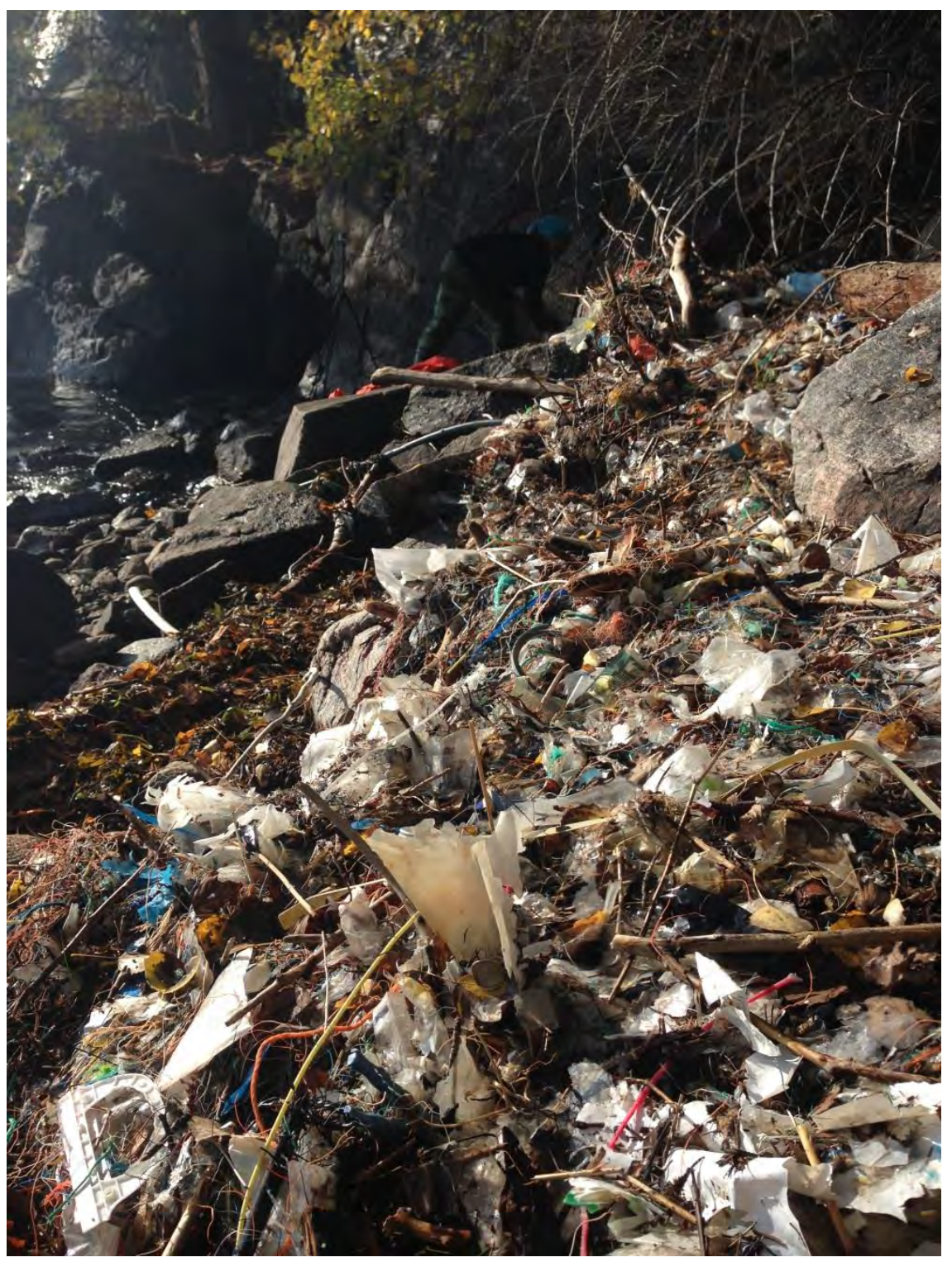

Overall, $3 \mathrm{~m}^{3}$ of litter was collected on the beach. $1 \mathrm{~m}^{3}$, or 12,198 litter items, was included in pick analyses as a representative sample of littering at the beach as a whole.

\subsubsection{Results and discussion}

The findings of the pick analysis of marine litter at Håøya showed a very high amount of plastic and polystyrene (95\%), which is an expected result (Figure 14). The OSPAR monitoring data from Norway shows sim- 
ilar results (Oslofjord Outdoor Recreation Council, personal communication). Glassware represents $3 \%$ of the total number of litter items, with other litter categories each accounting for less than $2 \%$ of the total number of objects.

Figure 14. The most common material types of marine litter at Håøya, Norway. Categories with few objects ( $<1 \%$ ) include; wood, rubber, metal, textile/clothes, paper/corrugated paper, dog faeces in bags, sanitary items, and medical items

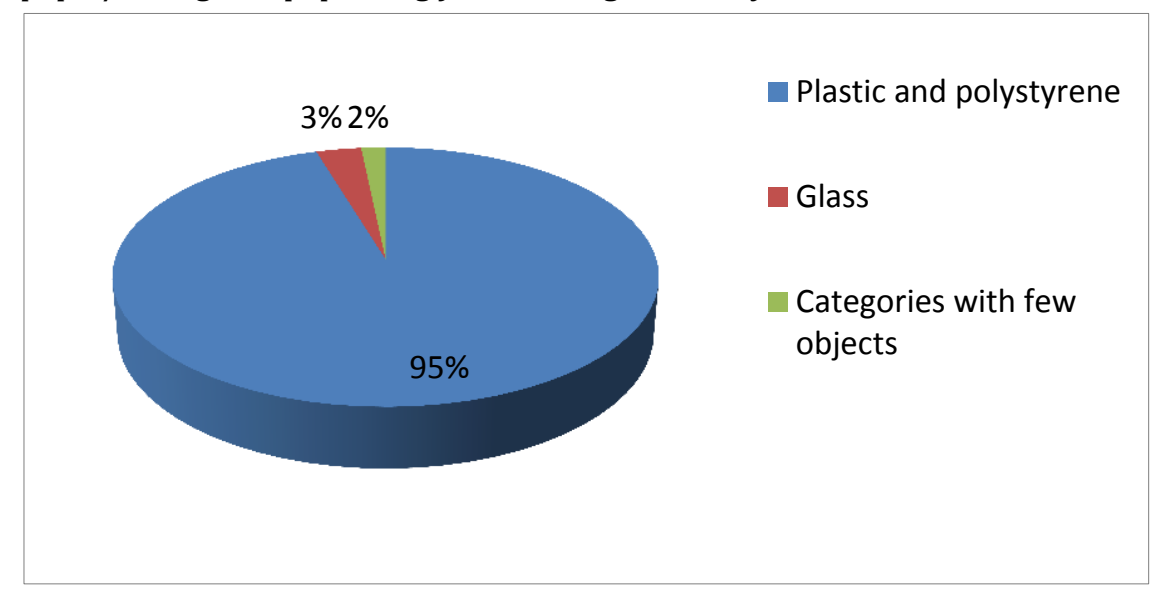

The result on source activity (Figure 15) shows that almost half the number of litter items were unidentifiable plastic fragments (45\%). $42 \%$ of the items were attributed to industry (plastic packaging from industry or farming), with only $13 \%$ coming from individual consumers.

Figure 15. Marine litter divided into source activities (\% of total number of litter items) from Håøya, Norway

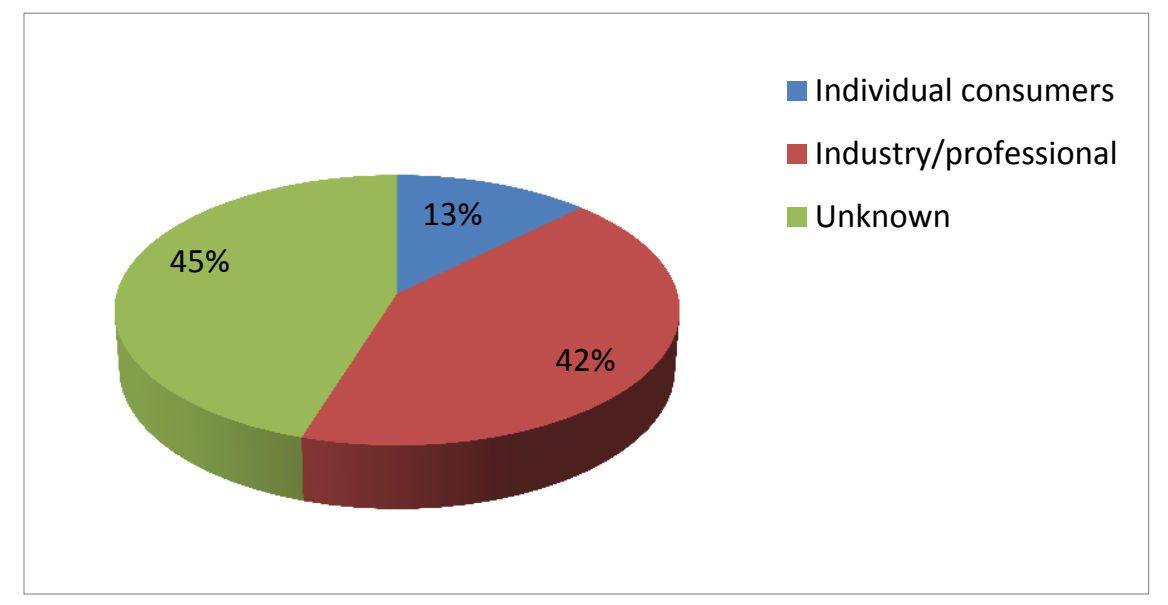


Figure 16 shows short life items as the most common category of use durability (60\%), whereas long use items made up 38\% of the total litter items collected.

Figure 16. Marine litter divided into use durability (\% of total number of litter items) from Håøya, Norway

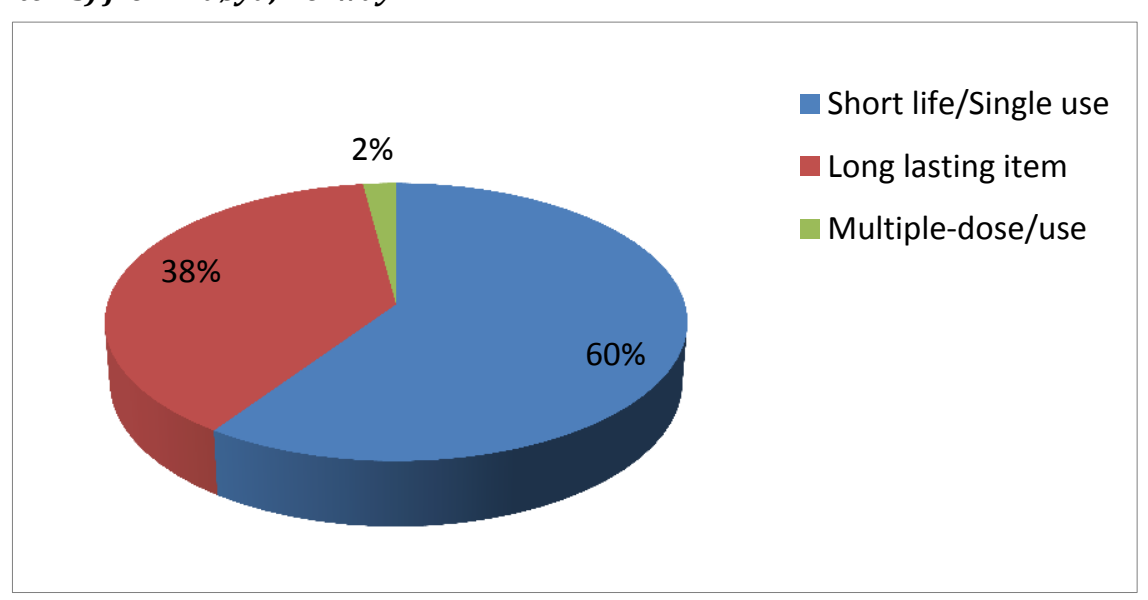

With regard to use categories, packaging was very common, constituting $65 \%$ of the total amount. Use items were $29 \%$, the rest being recreational items and raw materials. This is shown in Figure 17.

Figure 17. Marine litter divided into use categories (\% of total number of litter items) from Håøya, Norway

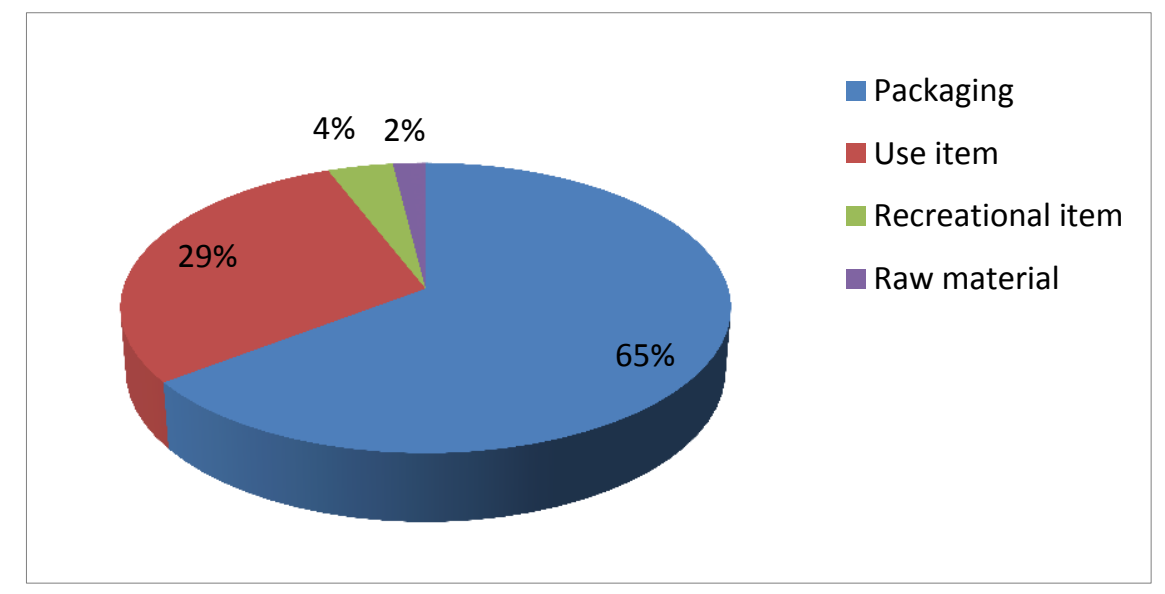

The study further found that $93 \%$ of the litter items had a degradation time in excess of 100 years. 


\subsection{Denmark}

\subsubsection{General information}

The collection of litter items for the pick analysis was carried out on Amager Beach Park in May 2014 during a Clean Beach event. This is a sandy beach outside Copenhagen frequently used by swimmers during the summer season. In total were 1,958 litter items analysed. Staff from Keep Denmark Tidy performed the pick analysis.

\subsubsection{Results and discussion}

The litter items from Amager Beach Park were categorised by material (Figure 18). Not surprisingly, the main part of the litter items consisted of plastic and polystyrene (78\%). The second most common litter material was paper $(11 \%)$, with other categories constituting a very small fraction of the total.

Figure 18. The most common material types of marine litter at Amager Beach Park, Denmark. Categories with few objects (<1\%) include; ceramics/porcelain, dog faeces in bags, and medical items

\begin{tabular}{|l|l|} 
口 & Plastic and polystyrene \\
& Paper/corrugated \\
paper \\
Wood
\end{tabular}


At Amager Beach Park, $80 \%$ of the beach litter can be associated with individual consumers compared to $19 \%$ related to industrial or professional sources (Figure 19). This is in line with the results of previous studies made by Keep Denmark Tidy, where approximately $80 \%$ of the beach litter on the east coast of Denmark originated from beach visitors. This is explained by the fact that the majority of these beaches are popular bathing beaches. The situation is the opposite on Denmark's west coast, where only $20 \%$ of the litter is related to beach visitors. (Hold Denmark Tidy, personal communication)

Figure 19. Marine litter divided into source activities (\% of total number of litter items) from Amager Beach Park, Denmark

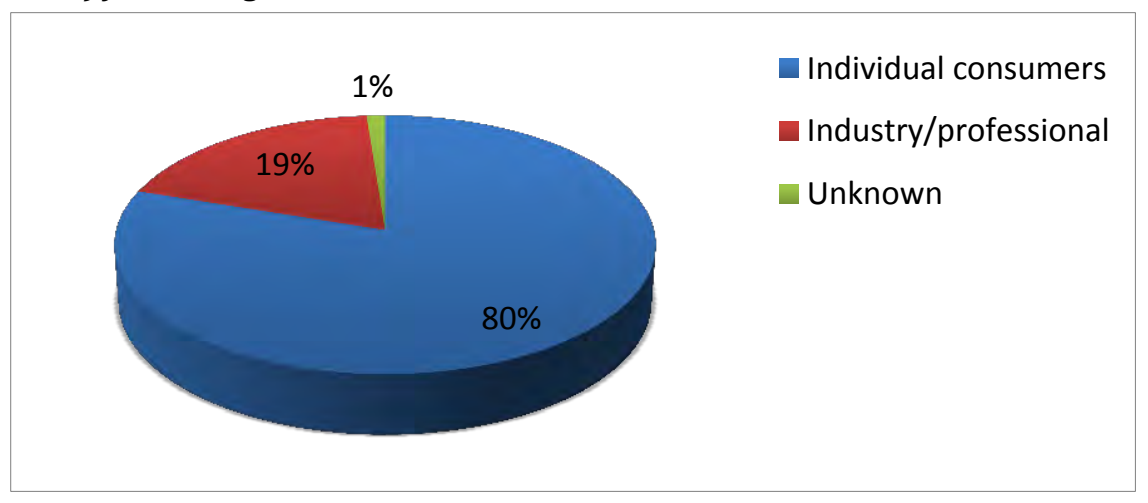

Figure 20 displays the use durability for litter items from the Danish beach. Almost all the litter found was categorised as short life or single use items. Only $3 \%$ of the litter items were multiple-dose/use and less than $1 \%$ was long lasting use.

Figure 20. Marine litter divided into use durability (\% of total number of litter items) from Amager Beach Park, Denmark

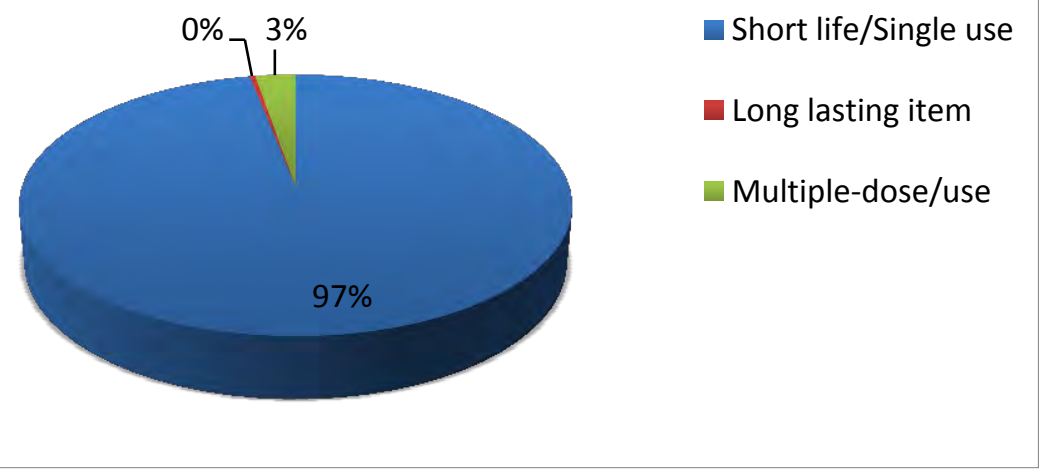


Packaging made up almost $78 \%$ of the litter items, with use items at $22 \%$ of the total (Figure 21). Four items were categorised as raw material and two as recreational items. This is not shown in the diagram since these two categories together were a very small part, only $0.3 \%$.

Figure 21. Marine litter divided into use categories (\% of total number of litter items) from Amager Beach Park, Denmark

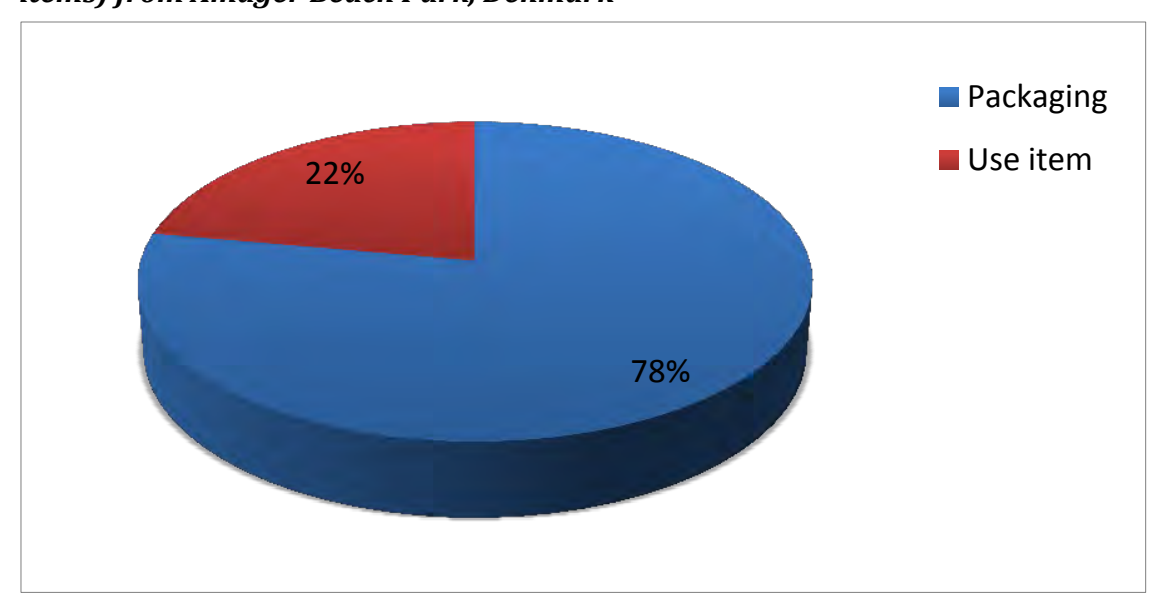

The degradation rate for $67 \%$ of the litter items was less than 100 years, the remainder having a degradation time of more than 100 years.

\subsection{Summary of results}

The results of this pilot study confirm that plastic and polystyrene are the most common materials in litter found on the beaches in all Nordic countries (Table 4). Single use items were the most commonly found categories in all beaches surveyed, mostly consisting of packaging (Table 5). Such litter items are strongly linked to individual consumers, which is reflected in the results (Table 5).

In Norway, however, the litter on the beach studied also consisted of lots of industrial packaging from the fishing and agricultural sectors, as well as packaging related to the transport of goods. This beach contained a relatively high proportion of objects with longer duration of use. On Håøya, and other OSPAR beaches around the North Sea, a lot of marine litter arrives from the open sea. The North Sea has very intense shipping traffic and other maritime activities such as fishing, offshore activities and aquaculture, affecting the quantity and variety of marine litter. Strong currents from the Atlantic Ocean towards the west coast 
of Sweden and south of Norway, together with frequent westerly winds, influence moreover where litter ends up.

The differences in litter items from the beaches studied are additionally explained by the differences in how the beaches are used. The beach in Norway and Utö in Finland are rural and has few visitors who could potentially litter. The beaches in both Sweden and Denmark are popular public beaches. Amager Beach Park outside Copenhagen is especially close to the city, with many visitors, including tourists.

Table 4. Top 5 litter materials found on the Nordic beaches included in this pilot study

\begin{tabular}{lr} 
& Percentage of total litter items (\%) \\
\hline Sweden & 89 \\
Plastic and polystyrene & 4 \\
Paper/corrugated paper & 2 \\
Glass & 1 \\
Metal & 1 \\
Other & \\
Finland & 58 \\
Plastic & 25 \\
Metal & 8 \\
Rubber & 8 \\
Glass and ceramics & \\
Norway & 95 \\
Plastic and polystyrene & 3 \\
Glass & 1 \\
Categories with few objects & 1 \\
Sanitary items & 0.2 \\
Rubber & \\
Denmark & \\
Plastic and polystyrene & \\
Paper/corrugated paper & 78 \\
Wood & 11 \\
Textile/clothes & 3 \\
\hline
\end{tabular}


Table 5. Summary of results from the pilot studies from the participating countries

\begin{tabular}{lcccc}
\hline & \multicolumn{2}{c}{ Percentage of total number of litter items } \\
& Sweden & Finland & Norway & Denmark \\
\hline Source activity & & & & \\
Individual consumers & 66 & n.a. & 13 & 80 \\
Industry/professional & 18 & n.a. & 42 & 19 \\
Unknown & 16 & n.a. & 45 & 1 \\
Use durability & & & & \\
Short life/Single use & 75 & 88 & 60 & 97 \\
Long lasting use & 24 & 10 & 38 & 0 \\
Multiple-dose/use & 1 & 2 & 2 & 3 \\
Use category & & & & \\
Packaging & 68 & 54 & 65 & 78 \\
Use item & 31 & 46 & 29 & 22 \\
Recreational item & 1 & 0 & 4 & 0 \\
Raw material & 0 & 0 & 2 & 0 \\
Fragmenting/Time of degradation & & & & 7 \\
Short (<100 year) & 7 & n.a. & 67 \\
Long (>100 year) & 93 & n.a. & 93 & 33 \\
\hline
\end{tabular}

n.a. = not analysed.

Differences in fragmentation/time of degradation between Denmark and Sweden/Norway may be explained by differences in categorisation.

Overall, the results from this pilot study identify patterns in the types of waste that is likely to end up as marine litter. It should be noted that this is a pilot study attempting an approach to categorising litter items that will give a different view than a conventional list. The approach has been used on litter items collected in clean-ups and in monitoring surveys. Thus there is no ambition to present a holistic picture or to make a deeper analysis of the comparison between countries at this stage.

As a complement to the results presented above, two examples of "top 10 lists" of litter items are presented in Table 6 and Table 7.

The "top 10 list" in Table 6 was collated using the litter items collected from Swedish beaches during the pick analyses. The litter items are divided at product level and do not follow the ordinary protocol used in Swedish beach litter monitoring. 
Table 6. A "top 10 list" of beach litter items from three beaches at the Swedish west coast in 2014

\begin{tabular}{lr}
\hline Litter items & Number of items \\
\hline Plastic bags & 5,354 \\
Unidentifiable plastic fragments & 2,021 \\
Polystyrene & 1,159 \\
Rope & 446 \\
Bottle caps and lids (plastic and metal) & 261 \\
Cigarette butts & 259 \\
Glass bottles & 168 \\
Disposable drinking cans & 158 \\
Straws/Stirrers & 115 \\
Toys & 43 \\
\hline
\end{tabular}

Many of the items in the "top 10 list" are made of plastic. This is consistent with litter materials found on Swedish beaches and elsewhere. Plastic bags were the most common item, followed by unidentifiable plastic fragments, polystyrene, ropes and bottle caps. Ropes are often made of plastic, as are bottle caps. Cigarette butts came in sixth place. Many of the litter items in the "top 10 list" are almost certainly related to consumers and short life products, also in accordance with the results from the other parameters included in the pick analyses.

The "top 10 list" of the most common litter items presented in Table 7 is based on items collected in Norway during Strandryddedagen 2014. The list shows an average of the litter items collected from beaches all over Norway. This and the information in the next paragraph is obtained from the report Strandryddedagen (Hole Skogen and Holen, 2014).

Table 7. A "top 10 list" of beach litter items from beaches in Norway 2014

\begin{tabular}{lr} 
Litter items & Number of items \\
\hline Unidentifiable plastic fragments & 130,037 \\
Polystyrene & 27,322 \\
Ropes shorter than $50 \mathrm{~cm}$ & 22,767 \\
Bottle caps and lids (plastic and metal) & 18,878 \\
Drink cans & 14,291 \\
Cigarettes or snuff & 11,421 \\
Food packaging & 10,113 \\
Rope longer than $50 \mathrm{~cm}$ & 9,387 \\
Plastic bags & 9,012 \\
Building materials & 2,966
\end{tabular}


Unidentifiable plastics were the most common items on Norwegian beaches. Polystyrene (also plastic material) is second in the list, and seems to be a growing problem as marine litter in Norway. Most of the polystyrene comes from the fishing industry and extra efforts should be targeted towards this occupational sector. This is also true for the third litter item on the list, rope, which usually originates from the boat- or fishing industry. Litter items that can be attributed to consumers include bottle caps, drink cans, cigarettes and food packaging.

From the tables above (Table 6 and 7) it is clear that there is a difference between the types of litter found in Norway compared to Sweden. This corresponds well with the results from the pick analyses in this project. 


\section{General discussion and conclusions}

This project is a first attempt to categorise litter items according to their sources by product. We present a different approach to measures for reducing litter in the marine environment by turning the focus towards not only categorising litter by activity (shipping, tourism, agriculture etc.) but by determining which products are most likely to end up as marine litter.

\subsection{Knowledge acquisition}

The project has shown that it is feasible to obtain further information on litter items both via monitoring surveys and beach clean-ups. Monitoring surveys are normally made by educated people and of higher quality. To use litter items from monitoring surveys are therefore preferable compared to items from beach clean-ups, if there are enough numbers to get a good statistical basis. Credible data is essential when it comes to influencing politicians and other decision makers.

In contrast, citizen science - the collection of data by many individuals - during clean-up activities yields large quantities of data, but also uncertainty over litter item collection methodology. Individuals have a tendency to pick particular types of litter and ignore other types. With clean-up activities, the location of the data collection may change from event to event, and the activities may not fit into the schedule of a monitoring programme. Citizen science provides indications about, for instance, how much litter is present on a beach. Such beach litter surveys by volunteers are also suggested by JRC-IES (2013) to keep the costs low. The information is moreover important in terms of communication. However, this method of acquisition may not provide data reliable enough to draw firm conclusions about the results. There should be a consideration between these pros and cons before deciding which method for collecting litter that should be used for beach litter categorisation. 
It can further be concluded that the protocol ${ }^{15}$ used in the pick analyses, which was developed during the project, is suitable for determining which products are most likely to become marine litter. Consequently, it is suggested that this protocol is incorporated in beach litter monitoring programmes in riparian states. A guideline/manual needs to be produced to get a harmonised approach for identification and categorisation of litter items. The amount of data required for pick analyses and source activity categorisation must also be decided. Important questions include how much litter should be analysed, from how many beaches, and how frequently? A long programme duration is also desirable, so that results become more reliable and show trends over time.

Often, NGOs and grassroots-level organisations are responsible for both beach clean-ups and beach litter monitoring. Such organisations therefore have an important role to play in the collection, analysis and storage of this information.

\subsection{Waste becomes marine litter}

The pilot study further confirms that single use plastic packaging is the most common type of beach litter. Marine litter is, consequently, largely a result of the modern production and consumption culture. Every individual has a responsibility to consider both what he/she is buying, and how the waste packaging is recycled. Roughly 600,000 tonnes of plastic packaging and 56,000 tonnes of PET bottles are introduced on the Nordic market annually. About $50 \%$ of plastic packaging waste is separated from other waste streams, and of this, 161,000 tonnes are recycled (Fråne, et al. 2014). The Packaging and Packaging Waste Directive states a minimum requirement for plastic recycling of $22.5 \%$. National recycling targets can, however, go further than this. The directive's target is fulfilled by Sweden, Norway and Finland. Denmark is also close to reaching the target. (Fråne, et al. 2014) Additionally, COWI (2014) reports that, compared to Sweden and Norway, Denmark has the highest amount of plastics in residual household waste and the lowest amount of plastic collected via packaging waste streams. Both Fråne et al. (2014) and COWI (2014) explain that this is because the three countries have

\footnotetext{
15 The protocol divides the litter items into composition, source activity, use durability, use category, and degradation time. This is explained in Chapter 4.2 Method.
} 
different implementations of the Packaging and Packaging Waste Directive. Norway and Sweden have established dedicated recycling organisations with specific collection arrangements, which is not the case in Denmark. From 1st May 2015, producers and importers of packaging/packaged products in Finland will be responsible for organising the collection and handling of consumer waste packaging. In reality, this will mean a phase-by-phase shift of the costs of waste collection and handling from the authorities to producers and importers. The deadline for this is 1st January 2016.

From the information above we can conclude that despite the fact that the Nordic countries have well-functioning recycling systems for packaging, great quantities of such waste nonetheless end up on coastlines as litter. Parts of the litter is likely from other countries but even so, there can be reasons to revise national recycling schemes. A forthcoming report ${ }^{16}$ from the Nordic Council of Ministers will present a guideline for best practices for systems of recycling in the Nordic countries.

The plastic and packaging industries also have an important role to play in the reduction of waste e.g. by using less plastic materials and avoiding unnecessary packaging through smart design. The producer's responsibility for waste is regulated in the Waste Framework Directive. In the EU Commission's communication on circular economy ${ }^{17}$ one of the proposed changes in the Waste Framework Directive (European Commission, 2014) extends the producer's responsibility for a product to include a post-consumption stage, including financial support for litter prevention and clean-up initiatives. Moreover, the Communication proposes a 30\% reduction target by 2020 for the ten most common litter items found on beaches, and industrial fishing waste at sea.

The pick analyses further show that the degradation time for most beach litter exceeds 100 years. It seems like a waste of resources to use material with such a long life-span for disposable items, as well as contributing to an accumulation of such items in the environment after use.

16 The 2nd part of the project "Improvements in existing collection and recycling systems of plastic waste from households and other MSW sources. The project is initiated by the Nordic Waste Group (NAG).

${ }_{17}$ Circular economy means that society should be based on a cycle instead of the linear model used today. 


\subsection{Raising awareness}

We can establish that consumers, and indirectly, the plastics and packaging industries contribute greatly to the amount of marine litter in the Nordic countries. Targeted actions should be deployed, especially preventive measures, and raising awareness amongst both individuals and producers is an important part of that work. Norway and the North Sea are an exception, however, since the professional sectors have a higher impact on the type of marine litter that is found.

The individual pattern of consumption and waste disposal is crucial to the amount of litter that is generated. This strongly correlates to public behaviour and attitudes towards litter. Increasing knowledge about a problem increases the likelihood that people will take responsibility for their behaviour, perhaps reducing the amount of litter produced.

NGOs have an important role to play informing, educating and raising awareness of the problem with marine litter. Beach clean-up events are one way of raising awareness, in that people see the results of the marine littering. A clean-up has the advantage of reaching out to, involving, and engaging a large portion of the public.

\subsection{Top 3 priorities for further work on marine litter in Nordic countries}

\section{Knowledge target}

Beach litter monitoring should work toward source identification in order to design useful action targets for reducing marine litter.

Data should be of high quality and gathered over long periods to identify trends. Monitoring of beach litter should preferably be undertaken by e.g. NGOs Even though the regional action plans in HELCOM and OSPAR support cooperation between riparian countries, it would be beneficial if the Nordic countries can continue to share data on both the composition and origin of litter.

\section{Policy targets}

The project supports the EU Commission's suggestions concerning extended responsibility for producers. Producers should, at a minimum, support litter prevention and clean-up activities to minimise the environmental impact of their products. Preventive measures should be prioritised over clean-up activities. Marine litter should be included in national waste plans - and also to a greater extent in local waste management plans. 
Measures tackling land-based sources should be the main focus when defining actions in the next phase of the Marine Strategy Framework Directive in 2016.

\section{Communication/outreach target}

Raising awareness is identified as an important preventive tool for reducing beach litter and should be directed at consumers (the public), as the project shows they are responsible for the majority of such litter. Measures should focus on changing behaviour relating to consumption, waste management and littering. NGOs arrange beach clean-up events to raise awareness about the problems caused by marine litter. By sharing experiences and cooperating on clean-up activities, e.g. by arranging a Nordic Beach Clean-up day, Nordic NGOs can be even more successful in their work. 



\section{Swedish summary}

Marint skräp är ett globalt miljöproblem som inte bara hotar de känsliga marina ekosystem och vilda djur; den har också stora socioekonomiska och estetiska konsekvenser. Marin nedskräpning har också en stark negativ koppling till ett hållbart samhälle. De flesta marina skräpföremål är tillverkade av plastmaterial och en allmän uppfattning är att $80 \%$ av det marina skräpet kommer från landbaserade källor. En viktig nyckel för att kunna föreslå kostnadseffektiva åtgärder är att identifiera källorna till skräpet. Bakgrunden till projektet är ett gemensamt intresse hos de nordiska frivilligorganisationerna till att samarbeta och utöka de aktiviteter som redan utförs, dvs. skräplockarkampanjer på stränder och miljöövervakning av strandskräp. En modell för skräpkategorisering ur ett produktperspektiv utvecklades i syfte att identifiera riktade begränsningsåtgärder av marint skräp.

Pilotstudierna i projektet bygger på plockanalyser av skräpföremål som samlats in under clean-up kampanjer eller i samband med miljöövervakning av strandskräp. Resultaten bekräftar att plast och frigolit är de vanligaste skräpmaterialen som hittas på undersökta stränderna i samtliga nordiska länder. Föremål för engångsbruk och förpackningar var också de vanligaste skräpen på alla stränder. Den här typen av föremål är starkt kopplad till enskilda konsumenter, även om det ska noteras att skräpet kan komma långt utanför gränserna till våra nordiska länder. Det marina skräpet kan därför till stor del hänvisas till vår tids produktion och konsumtion. På den studerade stranden i Norge däremot, kom många förpackningarna från industrin dvs. fiske- och jordbrukssektorerna samt förpackningar kopplade till transport av varor.

Projektet har visat att det är möjligt att få ytterligare information om skräpföremål från miljöövervakningsundersökningar och skräpplockarevengemang. För att få data med hög kvalitet är skräpföremål plockade vid miljöövervakningen att föredra. Skräpplockaraktiviteter med många deltagare ger å andra sidan ett stort dataunderlag. Frivilligorganisationer och organisationer på gräsrotsnivå har en viktig roll i att samla in, analysera och lagra informationen.

Åtgärder kopplade till politiska mål för återvinning av avfall och de föreslagna förändringarna i EUs avfallsdirektiv diskuteras i rapporten. Detta innefattar bland annat att producentansvaret utvidgas och produ- 
centerna bör också ekonomiskt stödja förebyggandet av nedskräpning och initiativ för strandstädningar. Målet är att minska marint avfall med 30 \% till 2020 för de tio vanligaste skräpföremålen som finns på stränderna och för fiskeredskap som finns i havet. Slutsatsen är att plast- och förpackningsindustri har en viktig roll i detta sammanhang. Att öka medvetenheten hos allmänheten genom att ordna skräpplockarevenemang identifieras också som en viktig åtgärd mot marint skräp.

Även om de regionala handlingsplanerna inom HELCOM och OSPAR stödjer samarbetet mellan kustländer skulle det vara en fördel om de nordiska länderna kan fortsätta att dela data både vad det gäller skräpets sammansättning och källor för spridning samt utbyte av nationell kunskap och erfarenhet. Genom att dela erfarenheter och samarbeta kring evenemang, t.ex. genom att arrangera en nordisk skräpplockarkampanj, kan nordiska frivilligorganisationer bli ännu mer framgångsrika i sitt arbete mot den marina nedskräpningen. 


\section{References}

ARCADIS (2012) Case study on the plastic cycle and its loopholes in the four European regional seas areas. European Commission DG Environment Framework contract. ENV.D.2./ETU/2011/0041.

ARCADIS (2013) Marine Litter study to support the establishment of an initial quantitative headline reduction target -SFRA0025. European Commission DG Environment. Project number BE0113.000668.

Cheshire, A.C., Adler, E., Barbière, J., Cohen, Y., Evans, S., Jarayabhand, S., Jeftic, L., Jung, R.T., Kinsey, S., Kusui, E.T., Lavine, I., Manyara, P., Oosterbaan, L., Pereira, M.A., Sheavly, S., Tkalin, A., Varadarajan, S., Wenneker, B. \& Westphalen, G. (2009). UNEP/IOC UNEP Regional Seas Reports and Studies, No. 186; IOC Guidelines on Survey and Monitoring of Marine Litter. Technical Series No. 83.

COWI (2014). Plastic at recycling centres, Background. Background Report, phase 1. Nordic working papers, Feb 2014. Nordic Council of Ministers.

European Commission (2010). COMMISSION DECISION of 1 September 2010 on criteria and methodological standards on good environmental status of marine waters. Official Journal of the European Union (2010/477/EU).

European Commission (2013). Green paper. On a European Strategy on Plastic Waste in the Environment. COM(2013) 123 final. Brussels, 7.3.2013.

European Commission (2014). Towards a circular economy: A zero waste programme for Europe. Communication from the commission to the European parliament, the council, the European economic and social committee and the committee of the regions. Brussels, 2.7.2014 COM(2014) 398 final.

Fråne, A., Stenmarck, Å., Gíslason, S., Lyng, K-A., Løkke, S., zu Castell-Rüdenhausen, M. \& Wahlström, M. (2014). Collection \& recycling of plastic waste. Improvements in existing collection and recycling systems in the Nordic countries. TemaNord 2014:543. http://dx.doi.org/10.6027/TN2014-543

Hole Skogen, M. \& Holen, M. (2014). Strandryddedagen 2014. -Analyse av data og erfaringer. Hold Norge Rent og retursamarbeidet LOOP. In Norwegian.

Håll Sverige Rent (2014). Rapport från Kusträddarna. Om skräpet på den svenska västkusten. In Swedish.

Jambeck, J.R., Geyer, R., Wilcox, C., Siegler, T.R., Perryman, M., Andrady, R. \& Lavender Law, K. (2015). Plastic waste inputs from land into the ocean. Science. Vol. 347, no. 6223, pp. 768-771. http://dx.doi.org/10.1126/science.1260352

JRC-IES (2013). A guidance document within the Common Implementation Strategy for the Marine Strategy Framework Directive. MSFD GES Technical Subgroup on Marine Litter. EUR 26113 EN - 2013.

Mehlhart, G. \& Blepp, M. (2012). Study on land-sourced litter (LSL) in the marine environment. Review of sources and literature. In the Context of the Initiative of the Declaration of the Global Plastics Associations for Solutions on Marine Litter. Report from the Öko-Institute e.V. - Institute für angewandte Ökologie.

Newman, S., Watkins, E. \& Farmer, A. (2013). How to improve EU legislation to tackle marine litter. Institute for European Environmental Policy, London. 
OSPAR (2009). Marine litter in the North-East Atlantic Region: Assessment and priorities for response. London, United Kingdom.

Sherrington, C. \& Darrah, C. (2014). Feasibility study - Litter Pathways to the Aquatic Environment. Eunomia research and consulting for Clean Europe Network.

Standal, E., Mathisen, R., Hildonen, H. \& Pettersvik Arvnes, M. (2014). Kunnskap om marine forsøpling i Norge 2014. Miljødirektoratet M-265/2014. In Norwegian.

Strand, J., Tairova, Z., Danielsen, J., Würgel Hansen, J., Magnusson, K., Naustvoll, L-J. \& Kirk Sørensen, T. Marine litter in Nordic waters. Unpublished manuscript. The Nordic Council of Ministers.

Svärd, B. (2013). Analys av data från OSPAR:s referensstränder åren 2001-2011. Ren Kust i Bohuslän. In Swedish.

Tudor, D. \& Williams, A. (2004). Development of a "Matrix Scoring Technique" to determine litter sources at a Bristol Channel beach. Journal of Coastal Conservation 9: 119-127. Opulus Press, Uppsala. http://dx.doi.org/10.1652/14000350(2004)010[0119:DOAMST]2.0.CO;2

UNEP (2005). Marine Litter. An analytical overview. Nairobi: UNEP 2005.

UNEP (2009). Marine Litter: A Global Challenge. Nairobi: UNEP 2009. 
Ved Stranden 18

DK-1061 Copenhagen K

www.norden.org

\section{Marine Littering and Sources in Nordic Waters}

Marine litter is a global environmental problem that endangers wildlife and has great socio-economic and aesthetic impacts. To identify sources of marine litter is an important key in order to propose cost-effective measures. Pick analyses of beach litter have therefore been conducted in order to categorise litter items from a product perspective. The results confirm that plastic are the most common litter material found on beaches in the Nordic countries. Short life items and packaging are dominating, which is strongly linked to individual consumers. It is further concluded that the plastics and packaging industry has an important role to play to decrease the amount of marine litter.

TemaNord 2015:524

ISBN 978-92-893-4061-8 (PRINT)

ISBN 978-92-893-4063-2 (PDF)

ISBN 978-92-893-4062-5 (EPUB)

ISSN 0908-6692

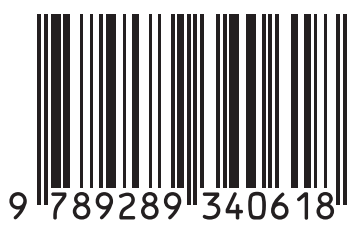

